\title{
Review
}

\section{The Mitochondrial Secret(ase) of Alzheimer's Disease}

\author{
Kisha J. Young ${ }^{\mathrm{a}}$ and James P. Bennett ${ }^{\mathrm{b}, *}$ \\ ${ }^{a}$ Neuroscience Graduate Program and Medical Scientist Training Program, University of Virginia School of \\ Medicine, Charlottesville, VA, USA \\ ${ }^{\mathrm{b}}$ Department of Neurology, Virginia Commonwealth University, Richmond, VA, USA
}

Accepted 24 March 2010

\begin{abstract}
Alzheimer's disease (AD) is a neurodegenerative disorder characterized clinically by progressive decline in memory and cognition and pathologically by extracellular amyloid- $\beta(\mathrm{A} \beta)$ deposits and intraneuronal aggregates of hyperphosphorylated tau. Since its proposal in 1992, the amyloid cascade hypothesis implicates A $\beta$ overproduction as a causative event in disease pathogenesis, and this thinking has predominated the field's understanding of $\mathrm{AD}$ pathogenesis and the development of potential therapeutics (i.e., $\mathrm{A} \beta$-reducing agents). Though $\mathrm{A} \beta$ has been shown to induce $\mathrm{AD}$ pathology, unanswered questions for sporadic $\mathrm{AD}$ development suggests this hypothesis is best applied to familial disease only. The more recent mitochondrial cascade hypothesis is supported by data showing that early impairments of mitochondrial dysfunction and oxidative stress may precede $\mathrm{A} \beta$ overproduction and deposition. However, the development of $\mathrm{A} \beta$-reducing agents continues. Unfortunately, these agents have not been efficiently tested for their effect on one of the earliest AD pathologies, i.e., mitochondrial dysfunction. This paper will review supporting data for the amyloid and mitochondrial cascade hypotheses, reports of the effects of secretase inhibitors on AD-phenotypic cells and animals, and begin to look at a potential role for $\gamma$-secretase, which is localized to mitochondria, in AD-related mitochondrial dysfunction.
\end{abstract}

Keywords: Alzheimer's disease, amyloid- $\beta, \gamma$-secretase, mitochondria, mitochondria-respiration

\section{INTRODUCTION}

A disease of progressive deterioration in memory and cognitive function, Alzheimer's disease (AD) is a neurodegenerative disorder of older age, which initially reduces ability to recollect recent events and later progresses to problems with language, visuospatial skills, judgment, and problem solving [1]. Affected individuals may also experience personality changes, sleep disturbances, and disorientation to time and place $[1$,

\footnotetext{
*Correspondence to: James P Bennett, MD, PhD, Department of Neurology, Virginia Commonwealth University, PO Box 980599, 1101 East Marshall Street, Richmond, VA 23298-0599, USA. Tel.: +1 804828 9720; Fax: +1 804828 6373; E-mail: jpbennett@vcu. edu.
}

2]. A clinical diagnosis of probable $\mathrm{AD}$ depends on the presence of impairments in memory and a second cognitive area affecting an individual's activities of daily living, without evidence of other systemic or neurological disorders that may mimic the same symptoms. Currently, a definitive diagnosis of AD can only be made with postmortem findings of two pathognomic features: extracellular deposits of amyloid- $\beta(\mathrm{A} \beta)$ containing plaques and intraneuronal aggregates of hyperphosphorylated tau. Depending on the dementia stage, there is also neuronal loss in the hippocampus and frontal cortex. Displaying significant atrophy of the hippocampus and frontal cortex seen on CT scan and on autopsy, $\mathrm{AD}$ brains also show significant oxidative stress, inflammation, cholinergic dysfunction, and synaptic degeneration [3-8]. Which pathological le- 
sion is the earliest marker of the disease's etiology has remained controversial, since each is associated with other aspects of disease pathology and can ultimately contribute to neuronal death. Among the list, the roles of $\mathrm{A} \beta$ overproduction and mitochondrial dysfunction in $\mathrm{AD}$ etiology have been under investigation for some time and have led to the development of two theories for $\mathrm{AD}$ development: the amyloid cascade hypothesis and the mitochondrial cascade hypothesis. In addition to their individual hypothesized roles in AD pathogenesis, mitochondrial and $\mathrm{A} \beta$ abnormalities appear to have a circular cause-and-effect relationship to one another. This review will discuss $\mathrm{A} \beta$ and mitochondria as they relate to what is currently understood about AD pathogenesis, as well as how they and their related proteins may work for or against one another in disease development and therapy.

\section{AMYLOID CASCADE HYPOTHESIS: MECHANISMS AND THERAPEUTICS FOR A $\beta$ PATHOLOGY}

First described by Hardy and Higgins in 1992, the amyloid cascade hypothesis pinpoints the overproduction of $\mathrm{A} \beta$, the major component of amyloid plaques, as the initiating event in AD pathology, occurring upstream to the development of tau tangles, neuronal death, and declining cognitive function [9]. The strength of this theory lies in the following evidence: 1 ) in familial and Down syndrome cases of AD, point mutations and duplications in $\mathrm{A} \beta$ 's parent amyloid- $\beta$ protein precursor $(\mathrm{A} \beta \mathrm{PP})$ lead to early onset $\mathrm{AD}[10$ 13]; 2) in vitro and in vivo studies have connected $\mathrm{A} \beta$ generation and oligomerization with the reproduction of AD-related pathologies: tau hyperphosphorylation, inflammation, oxidative stress, synaptic dysfunction, and memory deficits in cell and animal models [1422]; and 3) early observations of reductions in $\mathrm{A} \beta$ levels $[23,24]$ appear to rescue AD-related pathologies in cell and animal models $[25,26]$.

$\mathrm{A} \beta$ is a cleavage product of $\mathrm{A} \beta \mathrm{PP}$, a type 1 integral membrane glycoprotein encoded for on chromosome 21 , ubiquitously expressed in human tissues, and localized to the plasma membrane, endoplasmic reticulum, Golgi apparatus, and mitochondria $[27,28]$. To date, the function of $\mathrm{A} \beta \mathrm{PP}$ is not completely understood, but is suggested to have roles in cell adhesion, synaptic function, or neural plasticity $[29,30]$. A $\beta$ PP's intracellular and extracellular domains are conserved across other species' protein types (i.e., APL-1, AP-
PL, APLP1, and APLP2); however, the $\mathrm{A} \beta$ peptide domain is distinctive to mammalian $\mathrm{A} \beta \mathrm{PP}$ and is not necessary for the physiological function of the $\mathrm{A} \beta \mathrm{PP}$ species $[29,30]$. Several isoforms of $\mathrm{A} \beta \mathrm{PP}$ exist due to alternative splicing, with A $\beta$ PP695 predominately expressed in neurons. However, in sporadic AD (sAD), two reports reveal a ratio shift towards the neuronal expression of $\mathrm{A} \beta \mathrm{PP}$ isoforms other than $\mathrm{A} \beta \mathrm{PP} 695[31$, $32]$, and additional reports indicate alterations in $\mathrm{A} \beta \mathrm{PP}$ expression in platelets of AD individuals [33-35]. In addition to alternative splicing, $\mathrm{A} \beta \mathrm{PP}$ may be truncated on the carboxyl end to form smaller and less amyloidogenic fragments. Based on suggestions that nonneuronal isoforms and truncated forms may differ in amyloidogenicity, mRNA transcription alterations and posttranslational processing may serve as important determinants for increased $\mathrm{A} \beta$ production in $\mathrm{SAD}$, which makes up more than $90 \%$ of all AD cases compared to familial AD (fAD).

$\mathrm{A} \beta \mathrm{PP}$ is sequentially cleaved by two of three enzymes: $\alpha-, \beta-$, and $\gamma$-secretases. $\mathrm{A} \beta \mathrm{PP}$ is initially cleaved by $\alpha$ - or $\beta$-secretases at its $\mathrm{N}$-terminus, producing either soluble $\mathrm{A} \beta \mathrm{PP} \alpha$ or $\mathrm{A} \beta \mathrm{PP} \beta$, respectively. $\alpha$-secretase cleaves within the $\mathrm{A} \beta$ domain, precluding the generation of $\mathrm{A} \beta$ peptides. The remaining peptide (C83 after $\alpha$-secretase cleavage or C99 after $\beta$ secretase cleavage) is then cleaved by $\gamma$-secretase to produce the non-amyloidogenic p3 fragment (after $\alpha$ secretase) or amyloidogenic (fibril-forming) A $\beta$ peptide (after $\beta$-secretase) [36,37]. This naturally occurring cleavage sequence differs from $\mathrm{AD}$ pathogenesis only in that $\mathrm{A} \beta$ production and deposition are increased and accelerated in the disease. $\mathrm{A} \beta$ peptides can be 39-46 amino acids in length depending on the site of $\gamma$-secretase cleavage, with $\mathrm{A} \beta_{40}$ and $\mathrm{A} \beta_{42}$ being the most abundant and relevant to $\mathrm{AD}$ pathogenesis. Secreted $\mathrm{A} \beta_{40}$ is more abundant overall, but $\mathrm{A} \beta_{42}$ production increases and is more prevalent in amyloid plaques and cerebral vasculature in familial and sporadic forms of $\mathrm{AD}[38,39]$. In $\mathrm{ADD}, \mathrm{A} \beta \mathrm{PP}$ mutations located at or near secretase cleavage sites exist and decrease the $\mathrm{A} \beta_{40} / \mathrm{A} \beta_{42}$ ratio $[10,11,38]$, probably by altering the conformation of $\gamma$-secretase when it binds to mutated $\mathrm{A} \beta \mathrm{PP}[40]$. But so far, no mechanism for regulating $\gamma$-secretase specificity at the $\mathrm{A} \beta_{42}$-generating site of C99 has been identified in SAD. This mechanism, once identified, could serve as a potential target in AD drug development according to the amyloid cascade hypothesis. Once generated, $\mathrm{A} \beta_{40}$ and $\mathrm{A} \beta_{42}$ readily aggregate, first forming small and then larger oligomers, and then producing fibrils that can be deposited into the 
extraneuronal space. $\mathrm{A} \beta_{42}$ overproduction is studied as the causal event in the amyloid cascade theory because it demonstrates greater aggregation and stabilization than $\mathrm{A} \beta_{40}$, as well as increased neurotoxicity and synaptotoxicity [41-45]. Early in the discovery of $\mathrm{A} \beta$ toxicity in $\mathrm{AD}$, it was thought that the fibrillar form found within amyloid plaques was the most detrimental to neurons and synapses. However, the inability to correlate amyloid plaque levels with level and distribution of neurodegeneration and cognitive decline weakened this case $[46,47]$. Later, evidence for the toxicity by the soluble, oligomeric form of $\mathrm{A} \beta_{42}$ emerged, with specific evidence citing its role in synaptic plasticity disruption, calcium dysregulation, tau hyperphosphorylation, reduced mitochondrial respiratory protein activity, increased oxidative stress, and neuronal death [15, 17,20,22,48-52].

The amyloid cascade theory is highly reliant on a combination of data from Down syndrome, fAD, and transgenic mouse models, where the overexpression or mutation of proteins responsible for $\mathrm{A} \beta$ production demonstrates $\mathrm{A} \beta$ as the causative factor in the initiation and progression of tau hyperphosphorylation, mitochondrial and synaptic dysfunction, and apoptotic cell death. Inhibition of $\beta$ - or $\gamma$-secretase or upregulation of $\alpha$-secretase have been proposed as potential therapeutic targets by the amyloid cascade hypothesis, which suggests that targeting the generation, oligomerization, or clearance of $\mathrm{A} \beta$ could lead to a recovery or slowed decline of neurodegeneration. This hypothesis and the upregulation of $\beta$ - and $\gamma$-secretase activity in the brains of AD individuals make the targeting of these enzymes a highly probable therapy. The major class of drugs currently under investigation for $\mathrm{A} \beta$-reducing therapy is traditional $\beta$ - and $\gamma$-secretase inhibitors, but enhancers of $\alpha$-secretase activity have been proposed as well. In an effort to identify the most effective therapy, it is crucial to understand how the characteristics of each enzyme relate to $\mathrm{AD}$ pathogenesis.

The $\beta$-site A $\beta$ PP cleaving enzyme (BACE1 and its homologue BACE2) is the aspartyl protease responsible for $\beta$-secretase activity and the production of sA $\beta \mathrm{PP}$ and C99 peptide [53], which is subsequently cleaved by $\gamma$-secretase. The brains of individuals with SAD display increased BACE1 protein and activity levels, in addition to increased levels of its cleavage product $\mathrm{A} \beta \mathrm{PP}[54,55]$. This increase in $\beta$-secretase activity is also apparent in mild cognitive impairment (MCI), a prodrome to $\mathrm{AD}$, making it feasible that early increases in activity provide large amounts of $\mathrm{A} \beta$ that can exert pathological effects on mitochondria, tau protein, and synapses. In accordance with the amyloid cascade hypothesis, homogeneous and heterogeneous BACE1 knockouts eliminate or reduce $\mathrm{A} \beta$ generation, decrease plaque formation, and improve synaptic plasticity and memory of transgenic AD mice [56-58]. This improvement in synaptic plasticity and memory associated with reduced $\mathrm{A} \beta$ levels strengthens the case for using BACE1 as a therapeutic target. $\beta$-secretase inhibitors are still in early stages of development and clinical trial testing $[59,60]$. Therefore information on the efficacy is very limited at this time.

Since the function of $\mathrm{A} \beta \mathrm{PP}$ and its cleavage products are not well understood, another emerging theory is that increased production of $\mathrm{A} \beta$ coincides with reduced levels of $\mathrm{A} \beta \mathrm{PP}$ and other potentially beneficial cleavage products $[61,62]$. The enzyme responsible for the production of non-amyloidogenic $\mathrm{A} \beta \mathrm{PP}$ products is $\alpha$-secretase, a zinc metalloproteinase (ADAM9, ADAM10, and ADAM17/TACE) that releases soluble $\mathrm{sA} \beta \mathrm{PP} \alpha$, a peptide suggested to have neuroprotective properties $[63,64]$. ADAM10 is necessary to reduce $\mathrm{AD}$ plaques and improve learning and memory in mouse models $[65,66]$. Overexpression or upregulation of $\alpha$-secretase activity by agents like copper [67], muscarinic agonists, anti-cholesterol agents, and nonsteroidal anti-inflammatory drugs (NSAIDs) [63] has been proposed as a potential AD therapeutic because: 1) $\alpha$-secretase activity precludes the generation of $\mathrm{A} \beta$ by $\beta$-secretase cleavage and would therefore increase production of the non-amyloidogenic, potentially neuroprotective cleavage products of $\mathrm{A} \beta \mathrm{PP}$ [68] and 2) reports of reduced levels of the $\alpha$-secretase and its cleavage product $(\mathrm{sA} \beta \mathrm{PP} \alpha)$ in platelets and cerebrospinal fluid of AD subjects have been made [69-71]. This reduction in an $\alpha$-secretase cleavage product raises questions of whether $\mathrm{A} \beta$ overproduction is due directly to rises in $\beta$-secretase activity or indirectly through depressed $\alpha$-secretase activity that makes A $\beta$ PP more available for $\mathrm{A} \beta$-generating cleavage, and it has potential as a potential biomarker because of its correlation with pre-clinical and clinical stages in patients with Swedish mutation AD [71]. Whether this reduction in $\alpha$-secretase cleavage product is a response to increased $\beta$-secretase cleavage and reduced availability of the $\alpha$ secretase substrate [55] or an otherwise unknown cause of reduced $\alpha$-secretase activity with a subsequent response in increased $\beta$-secretase activity still remains to be understood, but the identification of a direct relationship in the activities of $\alpha$ - and $\beta$-secretase proteins would assist in determining which enzyme's activity is affected first by the inciting event for AD pathogenesis. 
Table 1

$\gamma$-secretase targets and their cleavage sites. $\gamma$-secretase cleaves a number of transmembrane proteins at the sites indicated. For some proteins ( $\mathrm{A} \beta \mathrm{PP}$ and Notch), presenilin demonstrates the ability to cleave at multiple sites, resulting in products of varying lengths. The peptide sequence of $\mathrm{A} \beta$ is bolded

\begin{tabular}{|c|c|c|}
\hline Known Target & Size & Cleavage Site \\
\hline 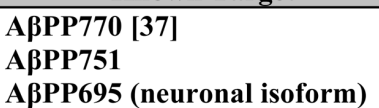 & $\begin{array}{l}770 \mathrm{aa} \\
751 \mathrm{aa} \\
695 \mathrm{aa}\end{array}$ & $\begin{array}{l}\text { SGLTNIKTEEISEVKMDAEFRHDSGYEVHHQKLVF } \\
\text { FAEDVGSNKGAIIGLMVGGV IA TVIVITLVML }\end{array}$ \\
\hline Notch 1 [195] & 2555 аa & $\begin{array}{l}\text { VQSETVEPPPPAQLHFMYVAA AAFVLLFFVGC GV } \\
\text { L LSRKRRRQHGQLWFPEG }\end{array}$ \\
\hline ErbB4 [193] & & PLIAAGVIGGLFILVIVGLTFA VYVRRKSIKKKRALR \\
\hline E-cadherin [82] & 901 aа & EAGLQIPAILGILGGILALLILILLLLLFL RRRAVVKE \\
\hline p75NTR [80] & $427 \mathrm{aa}$ & $\begin{array}{l}\text { PVVTRGTTDNLIPVYCSILAAVV YGLVAYI } \\
\text { AFKRWN }\end{array}$ \\
\hline
\end{tabular}

EMBL/GenBank/DDBJ databases.

Results from Kim and colleagues [72] suggest A $\beta$ PP cleavage activity by $\alpha$-secretase and $\beta$-secretase were not directly linked when inhibitors against TACE or BACE were used and the $\beta$ - and $\alpha$-secretase cleavage products were measured. Though brain $\beta$-secretase levels have been reported as increased, to our knowledge, no reports of alterations in brain $\alpha$-secretase levels in AD individuals have been made. Therefore, with the data presently available to us, we know that $\mathrm{A} \beta$ overproduction could be due to independent decreases or increases in $\alpha$ - or $\beta$-secretase activity.

$\gamma$-secretase is a protein complex made up of enzymatically-active presenilin 1 or 2 (PS1, PS2), nicastrin (NCT), presenilin enhancer 2 (PEN2), and anterior pharynx-defective phenotype (APH-1). Discovery of PS 1 as the catalytic enzyme responsible for $\mathrm{A} \beta$ generation occurred when PS1-/- mice were found to have decreased $\mathrm{A} \beta$ levels, in addition to altered skeletal and brain development [73]. It was further supported by evidence of $\gamma$-secretase deficiency in models of PS1 and PS2 mutations [74,75]. PS1 and PS2 are homologous aspartyl proteases whose genes are mapped to chromosomes 1 and 14, respectively [76-78]. In addition to $\mathrm{A} \beta \mathrm{PP}$ cleavage, the $\gamma$-secretase complex is responsible for processing of Notch, E-cadherin, ErbB4, and p75NTR (Table 1) [74,79-83], and loss of function in one enzyme can be partially compensated by the other PS, though activity is usually reduced. Substrate recognition is dependent on NCT function, while assembly of the complex occurs via the scaffolding function of APH-1 [84]. APH-1a, which has two splice variants (APH-1aS and APH-1aL), and APH-1b are homologous proteins that together with PS1 and PS2 can form up to six distinct $\gamma$-secretase complexes [85]. After assembly of PS1/PS2, NCT, and APH-1aS/APH$1 \mathrm{aL} / \mathrm{APH}-1 \mathrm{~b}, \mathrm{PEN} 2$ binds to activate and stabilize the complex $[84,86]$. The ability of the four components to form up to six distinct complexes suggests each may possess different substrate affinities and serve importance in specific environments. Some authors have also suggested that other proteins associated with the $\gamma$ secretase complex, like TMP21, may assist in determining the cleavage specificity of the enzyme with its substrates [87-90], further suggesting a physiological regulation of substrate recognition and target processing. Mutations in PS1 are responsible for over 50\% of fAD cases and are highly penetrant before the age of 65 [88-90]. These PS mutations tend to shift the cleavage specificity of $\mathrm{C} 99$ to increase generation of $\mathrm{A} \beta_{42}$ [91], possibly by altering $\gamma$-secretase conformation to decrease or increase binding of the enzyme with the $\mathrm{A} \beta$ residues responsible for forming $\mathrm{A} \beta_{40}$ or $\mathrm{A} \beta_{42}$, respectively [92]. PS2 mutations are less abundant, but also lead to increased $\mathrm{A} \beta_{42}$ production. Additional genetic and environmental factors appear to be responsible for variations in penetrance because PS2 mutations tend to have variations in age of onset and symptom severity, even within the same pedigree [93]. These variations were not accounted for by apolipoprotein $\mathrm{E}$ (ApoE) polymorphisms [93,94], of which APOE $\varepsilon 4$ is associated with increased risk for AD [95].

Intramembranous cleavage of $\mathrm{A} \beta \mathrm{PP}$ is dependent on aspartate (Asp) residues in the transmembrane domain of PS1, leading to a loss or gain of $\gamma$-secretase function when Asp257 or Asp385 are deleted or mutated [79]. In addition, these Asp residues affect the ability of PS1 to cleave its other transmembrane protein targets [79,96-98]. However, interactions with an important nucleotide-binding site on PS1 can preferentially block or increase A $\beta$ PP cleavage, while sparing alterations to Notch processing [99]. The specificity of $\gamma$-secretase for A $\beta$ PP versus Notch can also be con- 
trolled by Rac1, a G-protein suggested to play a role in AD because it mediates platelet-derived growth factorinduced cleavage of $\mathrm{A} \beta \mathrm{PP}$ by $\beta$ - and $\gamma$-secretase [100]. It was also found that the Rac1 inhibitor, EHT 1864 , reduces the $\mathrm{A} \beta$-generating activity of $\gamma$-secretase without affecting its role in Notch1 cleavage [101]. Therapeutic targeting of $\gamma$-secretase specificity for its targets (or certain residues as is the case with PS1 mutations on $\mathrm{A} \beta \mathrm{PP}$ processing) would be beneficial for inhibiting the $\mathrm{A} \beta$-generating $\gamma$-secretase action, without unwanted side effects caused by inhibition of Notch or E-cadherin. The potential for multiple mechanisms that control substrate and residue recognition for the complex strongly supports its use in multiple pathways. Based on such observations, one could also speculate that additional pathways may be present in which $\gamma$ secretase works. The ability for presenilins to serve in multiple cleavage roles is of great importance because potential $\mathrm{AD}$ treatments must consider the impact of non-specific $\gamma$-secretase inhibition on the complex's other targets.

Non-specific $\gamma$-secretase inhibitors (GSIs) are effective in reducing $\mathrm{A} \beta$ production $[23,102]$ in brain, plas$\mathrm{ma}$, and cerebrospinal fluid, and the inhibitor DAPT (N[N-(3.5-difluorophenacetyl)-l-alanyl]-S-phenylglycine -t-butylester) demonstrates the ability to improve fear conditioning responses in a transgenic mouse model with the Swedish A $\beta$ PP mutation [25]. Though DAPT is a nonspecific inhibitor, its effect on cognition appears to be related to amyloid generation, as no effect on control animals was detected. In addition, results of reduced $\mathrm{A} \beta$ production and oxidative stress, improved mitochondrial membrane potential, and lessened vulnerability to apoptosis in a loss-of-function mutant of PS1 were replicated with use of DAPT [26]. These discoveries support the use of $\gamma$-secretase inhibitors in clinical trials, but non-specific $\gamma$-secretase inhibitors also inhibit Notch cleavage and signaling, resulting in side effects related to the gastrointestinal tract, thymus, and spleen. Therefore, the development of Notch-1 sparing inhibitors that selectively reduce $\mathrm{A} \beta$ has also become a major focus. The identification of a useful $\gamma$-secretase inhibitor must balance the concentration needed for $\mathrm{A} \beta$-lowering and cognition-enhancing effects with Notch-inhibiting effects. Notch-1-sparing GSI begacestat demonstrated selective inhibition of A $\beta$ PP cleavage over Notch cleavage in cells, a $52 \%$ reduction in brain $\mathrm{A} \beta_{42}$ in $\mathrm{Tg} 2576$ mice, and reversal of impaired contextual fear conditioning after oral dosing [103]. Currently in Phase III clinical trials, the notch-1-sparing GSI semagacestat (LY450139) was re- ported to reduce CNS A $\beta$ levels by $47-84 \%$ (depending on dose) in healthy men ages $21-50$ years of age when given orally [104]. However, it still remains to be seen if these inhibitors protect or enhance cognition in human subjects.

While we have much evidence for potential improvements by $\gamma$-secretase inhibitors, we must also acknowledge some conflicting evidence for the use of $\gamma$ secretase as a therapeutic target. While the amyloid hypothesis posits that presenilin mutations are involved in familial AD pathogenesis through the overproduction and accumulation of $\mathrm{A} \beta_{42}$, the newly discussed presenilin hypothesis suggests instead that presenilin mutations may result in a loss of physiologically important $\gamma$-secretase functions [105]. Saura and colleagues reported a conditional presenilin double knockout that recapitulates features of $\mathrm{AD}$, specifically impairments in synaptic plasticity and increased tau hyperphosphorylation and neuronal cell death [105], further raising questions for other physiological roles of this protein. Shen and Kelleher [91] thus proposed a hypothesis where loss of presenilin function leads to synaptic dysfunction, resulting in the tau hyperphosphorylation and neurodegeneration. In addition, they reviewed a number of PS1 and PS2 mutations that result in decreased $\mathrm{A} \beta_{40}$ production, reduced proteolysis of Notch and E-cadherin, and impaired $\gamma$-secretase-independent functions, such as the destabilization of $\beta$-catenin responsible for the downregulation of the Wnt signaling pathway. Though these reports of loss of function for $\gamma$-secretase may only represent an etiology for familial $\mathrm{AD}$, additional investigations may grant us further understanding of how important $\gamma$-secretase functions are altered in sporadic AD. In addition, while this recent data conflicts with the widely acknowledged role of $\gamma$-secretase in $\mathrm{A} \beta \mathrm{PP}$ processing and amyloid-induced neurodegeneration, understanding all of the potential roles of $\gamma$-secretase is crucial because an effect of $\gamma$ secretase inhibitors on oxidative phosphorylation and ATP production has not yet been reported. If mitochondrial bioenergetics can be pharmacologically improved, early pathogenesis of the disease may be halted and prevent disease progression.

Currently, some therapies originally developed for other AD pathologies as their targets (i.e., cholinergic dysfunction and inflammation) have come under investigation again for their potential role in $\mathrm{A} \beta \mathrm{PP}$ processing. The cholinergic system plays an important role in memory function, and acetylcholine (ACh) levels are reduced in $\mathrm{AD}$-affected brain regions [6]. In clinical trials, some cholinergic agonists and acetyl- 
cholinesterase (AChE) inhibitors have led to improvements in cognition and activities of daily living [106, 107], making these drugs one of today's first-line treatments. Cholinesterases can also cleave $\mathrm{A} \beta \mathrm{PP}$ and promote $\mathrm{A} \beta$ aggregation; therefore, besides their primary effect in increasing ACh levels, some inhibitors (e.g., rivastigmine) reduce $\mathrm{A} \beta$ generation and/or aggregation [108-111], while others (e.g., tacrine) reduce $\mathrm{A} \beta$ by inhibiting BACE activity [112]. Because $\mathrm{A} \beta$ can result in the loss of cholinergic neurons [14], this dual function could serve a synergistic function, first reducing $\mathrm{A} \beta$ levels and preventing cholinergic neuronal loss and second by increasing AChE present in the synaptic cleft to preserve and enhance memory. Initial efficacy by cholinesterase inhibitors in clinical trials has been documented, but unless cholinergic dysfunction is the major contributor to and/or early deficit in AD pathology, they have yet to demonstrate long-term efficacy and currently remain for symptomatic use only.

Epidemiological evidence and clinical trials suggest use of nonsteroidal anti-inflammatory drugs (NSAIDs) lowers AD risk [113,114]. Their anti-inflammatory nature makes NSAIDS a potential therapeutic against the AD-associated elevations in activated microglia and inflammatory cytokines. Some NSAIDs (e.g., ibuprofen, fluriprofen, and indomethacin) also possess the ability to reduce $\mathrm{A} \beta_{42}$ levels by modulating $\gamma$-secretase activity to preferentially generate the shorter, less amyloidogenic peptide $\mathrm{A} \beta_{38}$ [115-118]. The $\gamma$-secretase modulating feature of NSAIDs does not affect other targets of $\gamma$-secretase activity (i.e., Notch and other $\mathrm{A} \beta \mathrm{PP}$ cleavage products) and is thought to act synergistically with its anti-inflammatory effects; therefore, this was a promising step for AD therapy. However, A $\beta_{42}$-suppressing NSAIDs do not appear to provide additional protection against $\mathrm{AD}$ development in non-diagnosed individuals compared to non- $\mathrm{A} \beta_{42^{-}}$ suppressing drugs $[114,119]$, therefore debunking the hypothesis that its positive effects are mediated partially through lowering $\mathrm{A} \beta$. In addition, whatever the mechanism for NSAID effectiveness in preventative therapy in the short-term is, the data for their usefulness in already-diagnosed individuals is inconsistent. $\mathrm{A} \beta$ lowering NSAIDs indomethacin and the R-enantiomer of fluriprofen appear to reduce the progression of cognitive decline during short-term use (6-24 months) [4, 120]. However, for long-term therapy, the clinical trials for therapeutic use of NSAIDs in individuals already diagnosed with $\mathrm{AD}$ have not shown similar degrees of protection against advancing disease [24,121, 122], suggesting NSAIDs are unable to serve beyond a preventative capacity.
Although the amyloid cascade hypothesis still remains the leading theory in the field, the link in sporadic $\mathrm{AD}$ is weakened by a lack of evidence for a relationship between the pattern of amyloid deposition and cognitive dysfunction. It is also compounded by the difficulty in identifying correlative biomarkers based on systemic $\mathrm{A} \beta$ concentrations, and the high dependence on transgenic animal and familial models for developing therapeutics. Though the amyloid cascade hypothesis has been useful in identifying downstream effects of $\mathrm{A} \beta$ overproduction, its usefulness is limited to familial cases. These models are solely based on $\mathrm{A} \beta$ overproduction as the initiating event in $\mathrm{AD}$ pathogenesis, and therefore lack an explanation for the genesis event for $\mathrm{A} \beta$ overproduction in sporadic cases of AD. Therefore, a closer look at other, potentially earlier, forms of AD pathology is warranted. If identified, a genesis event triggering $\mathrm{AD}$ pathogenesis may be linked to $\mathrm{A} \beta$ overproduction.

Since the early classification and descriptions of $\mathrm{AD}$ and its pathologies, many hypotheses have been suggested; unfortunately, none fully explain the early events that trigger metabolic and cellular alterations in neuronal degeneration. Once fibrillar $\mathrm{A} \beta$, which makes up plaques deposits, was overshadowed by oligomeric $\mathrm{A} \beta$ as a causative neurotoxic agent towards neurons and synapses, it has brought back into question a long-time theory behind AD pathogenesis. Correlations between cognitive function and tau, synaptic dysfunction, and cerebral atrophy exist, but the role of overproduction and aggregation of $\mathrm{A} \beta$ is still perplexing because it appears to be involved in all aspects of AD pathogenesis and progression. If $\mathrm{A} \beta$ is the major initiating event for AD pathology, then its overproduction should show a relationship with pathology. In an effort to further elucidate an initiation event in $\mathrm{AD}$, it is important to consider and evaluate all hypotheses, as well as consider relationships between each that may make neurons more susceptible to neurodegeneration.

Two pieces of evidence missing from the preclinical drug investigations of prospective disease modifying anti-Alzheimer's drugs (DMAADs) include: 1) selectivity for non-A $\beta \mathrm{PP} /$ Notch $\gamma$-secretase substrates/activities and 2) a positive effect on mitochondrial function, already shown to be impaired early in the disease. The ubiquitous presence of $\gamma$-secretase also warrants further study for additional physiological roles because even Notch-sparing molecules may not avoid adverse effects of inhibiting other physiological functions, especially those related to mitochondria. There is also an increased need for the identification of 
therapeutic targets that are affected early on in disease pathogenesis. Therefore, the next step in AD research is to study the effect of these drugs on mitochondrial respiration. Since mitochondria are important for energy homeostasis, and impaired function is evident in many neurodegenerative diseases, this review will now delve into the relationship between $\mathrm{AD}$ and mitochondrial function, while also relating back to the contributions of other areas of AD pathology in the initiation or progression of impaired mitochondria function.

\section{MITOCHONDRIAL CASCADE HYPOTHESIS}

The mitochondrial cascade hypothesis was proposed by Swerdlow and Khan in 2004 as a suggestion for the development of sporadic $\mathrm{AD}$ in an aging population [123]. Based on emerging data for a significant role of mitochondrial dysfunction in $\mathrm{AD}$, the hypothesis states mitochondrial DNA (mtDNA) or protein damage may be responsible for declining mitochondrial function and increasing toxic side-products. Mitochondria, the "powerhouses" of the cell, are specifically known for their roles in cell bioenergetics and programmed cell death. For its role in bioenergetics, pyruvate from the cytoplasmic process of glycolysis is transported into mitochondria, which contain the Krebs cycle and the electron transport chain. The electron transport chain (ETC) consists of complexes I to $\mathrm{V}$, which sequentially oxidize NADH and $\mathrm{FADH}_{2}$, reduce $\mathrm{O}_{2}$ to $\mathrm{H}_{2} \mathrm{O}$, and pump protons across the inner membrane of the mitochondria, creating a proton-electrochemical gradient to produce adenosine triphosphate (ATP) from adenosine diphosphate (ADP) in a process known as oxidative phosphorylation [124]. AD-related impairments in mitochondrial function are most often described as decreases in the activity of electron transport chain enzymes, increases in reactive oxygen species (ROS), reductions in mitochondrial membrane potential, or reductions in ATP production. A decline in glucose metabolism in AD-associated brain regions occurs early in the transition from cognitively normal to MCI to $\mathrm{AD}$ and correlates with tau tangle pathology dementia severity [125]. The reduction in glucose metabolism may reflect a decline in mitochondrial electron and substrate transport, which is confirmed by the presence of neurons deficient in important ETC proteins and a rise in oxidative damage in AD and its prodrome MCI [126128]. It may also suggest a shift towards oxidationreduction reactions in other organelles, specifically the plasma membrane oxidoreductase system, which is known to be upregulated in cells lacking a functional mitochondrial respiratory system [129]. To date, increases in non-mitochondrial redox reactions have not been reported.

Though the primary event for mitochondrial dysfunction is not yet clear, according to the mitochondrial cascade hypothesis, declining mitochondrial function and increasing oxidative stress as a function of age precede and cause AD pathology, i.e., $\mathrm{A} \beta$ overproduction and deposition, synaptic degeneration and apoptosis, and tau hyperphosphorylation and aggregation [123]. Mitochondria serve as a normal and the major contributor of cellular oxidative stress, predominately through the electron transport occurring at complexes I and III $[130,131]$. During the transfer of electrons down the chain, electrons sometimes end up incompletely reducing oxygen, creating ROS like superoxide and hydroxyl radicals. Superoxide may also react with nitric oxide to form reactive nitrogen species, another source of cellular damage. Normal ROS levels serve a functional purpose, are generated in response to hypoxia, and trigger important processes that will increase cell and tissue survival [131], such as the stimulation of cell proliferation through the induction of protooncogenes $c$-fos, $c$-jun, and c-myc [132,133]. ROS production must maintain a fine balance because at high levels, it is also responsible for initiating apoptotic pathways [132]. Besides reaching levels needed for the initiation of programmed cell death, excess ROS oxidizes lipids, proteins, and DNA in the cellular or organelle wall, with the mitochondrial enzymes and mtDNA being highly accessible and their damage highly likely. The mitochondrial genome is particularly susceptible to oxidative damage because it is not protected by histones, has a lower ability to correct mistakes compared to the nuclear genome, and the proofreading subunit of its replicating polymerase (gamma) is itself a target of oxidative attack. Damage to mitochondrial enzymes and mtDNA can lead to additional mitochondrial problems that may result in greater ROS production, creating an ongoing circular chain of events (mtDNA alterations $\leftrightarrow$ ROS production). Constant exposure of $\mathrm{mtD}-$ NA to normal and abnormal levels of ROS throughout the lifespan of an individual is a likely explanation of the accumulation of new mitochondrial mutations and deletions $[134,135]$.

Thirteen proteins of the ETC are encoded for in mitochondria's $16.6 \mathrm{kB}$ circular, double-stranded DNA [136,137], and the occurrence of spontaneous or inherited mutations and deletions in mitochondrial DNA (mtDNA) can lead to severe diseases in neurons 
and muscles. Maintenance of normal mtDNA expression and bioenergetics are especially important in neurons because they are highly reliant on mitochondriaproduced ATP for energy and are non-regenerating cells; therefore, any pathological developments can remain, progress, and cause neurons to die. In an attempt to determine if neurodegenerative diseases process a large degree of mtDNA alterations similar to traditional mitochondrial diseases, a number of laboratories have studied and reported high levels of mtDNA mutations in AD individuals [138]. Though the specific mutations identified and their levels have been inconsistent across studies, an increase in mtDNA alterations is still thought to play a significant role in the development of neurodegenerative diseases like AD [138] because mtDNA mutations and deletions are known to accumulate with age $[139,140]$ and have the potential to reach a threshold at which mitochondrial function is affected. Neurons in aged and Parkinson's disease individuals demonstrate higher levels of mitochondrial alterations $[139,141]$. When $\mathrm{mtDNA}$ alterations are present, cytochrome oxidase, the enzymatically active component of complex IV, is predominately affected. Hippocampal neurons from AD brains have increased cytochrome oxidase (COX) deficiency compared to normal, aged individuals [126,142]. Loss of COX expression and activity of any ETC enzymes greatly contributes to reductions in ATP production and increases in oxidative stress, since the $\mathrm{O}_{2}$ reduced in the ETC would now be more accessible for oxidation by leaking electrons. Evidence for high levels of lipid peroxidation have been measured in the cerebrospinal fluid of AD individuals compared to non-demented elderly individuals [143].

The mitochondrial cascade hypothesis challenges the amyloid cascade hypothesis as an explanation for the onset of AD (Fig. 1). Supporters of the amyloid cascade hypothesis have used it to explain AD-related mitochondrial pathology because: 1) $\mathrm{A} \beta \mathrm{PP}$ and $\mathrm{A} \beta$ accumulates in mitochondria from brains of transgenic mice and $\mathrm{AD}$ subjects [144-147]; 2) binding of $\mathrm{A} \beta$ to the mitochondrial proteins $\mathrm{A} \beta$-binding alcohol dehydrogenase and cyclophilin D is associated with increased oxidative stress, cytochrome c release, reduced mitochondrial membrane potential, and neuronal cell death [146,148]; 3) features of reduced Krebs cycle and ETC enzymatic activity, impaired state 3 and state 4 respiration, and in vivo elevation of oxidative stress demonstrated in $\mathrm{AD}$ and transgenic mouse brains were associated with $\mathrm{A} \beta[126,149-155]$; and 4) the direct reduction of cytochrome oxidase expression and activ- ity by $\mathrm{A} \beta_{42}$ and $\mathrm{A} \beta_{25-35}$ (a toxic $\mathrm{A} \beta$ fragment) supported this hypothesis $[48,156,157]$. Though evidence for $\mathrm{A} \beta$-induced pathology is plentiful, PET-scan measured reductions in brain glucose metabolism in MCI and AD individuals [158-161] warrant a further look at the role mitochondrial bioenergetics play. In addition, it was recently reported that this deficit in mitochondrial bioenergy precludes an increase in $\mathrm{A} \beta$ production in transgenic mice and correlates well with clinical severity in humans $[125,145]$, further supporting the claim that oxidative stress occurs upstream to $\mathrm{A} \beta$ overproduction, which, according to the amyloid cascade hypothesis, was a primary event in AD-related mitochondrial dysfunction. Though evidence for mitochondrial dysfunction induced by $\mathrm{A} \beta$ exposure is useful in determining the progression of $\mathrm{AD}$ once induced, this latest discovery severely weakens the amyloid cascade hypothesis as a prominent theory for sporadic cases of AD.

\section{Secretase enzyme and mitochondrial dysfunction}

In accordance with the mitochondrial cascade hypothesis, the ability of $\mathrm{A} \beta$ to promote a decline in respiratory capacity and the existence of mitochondrial impairments prior to $\mathrm{A} \beta$ deposition suggests a link between the $\mathrm{A} \beta$-generating secretase enzymes, oxidative phosphorylation, and oxidative stress. First, increased BACE protein levels and activity in postmortem AD brain $[54,162]$ are linked to increased $\gamma$-secretase cleavage of $\mathrm{A} \beta \mathrm{PP}[163]$ and correlate with oxidative stress levels [164]. Endogenously and exogenously-induced ROS overproduction increases both BACE1 and PS1 expression and activity [165-168], which are mediated through the activation of the JNK pathway [169-171] and results in increased $\mathrm{A} \beta$ production $[161,172]$. In addition, Jo and colleagues report $\gamma$-secretase is responsible for ROS-induced increases in $\beta$-secretase activity, since pharmacological or genetic loss of $\gamma$-secretase function ameliorates an increase in $\beta$-secretase [173]. This upregulation of $\gamma$-secretase activity in oxidativelystressed environments further supports a link between the protein and mitochondrial function. The ability of mitochondrial dysfunction to lead to the production of a damage-promoting enzyme (i.e., $\mathrm{A} \beta$ ) raises important questions for what evolutionary advantage an increase in $\gamma$-secretase activity would provide for mitochondria. If other responses to oxidative stress include the triggering of pathways that increase survival of the cell, why would a cell decide to upregulate the activity of an enzyme that produces a protein that is 


\section{Amyloid Cascade Hypothesis} I. Mechanism

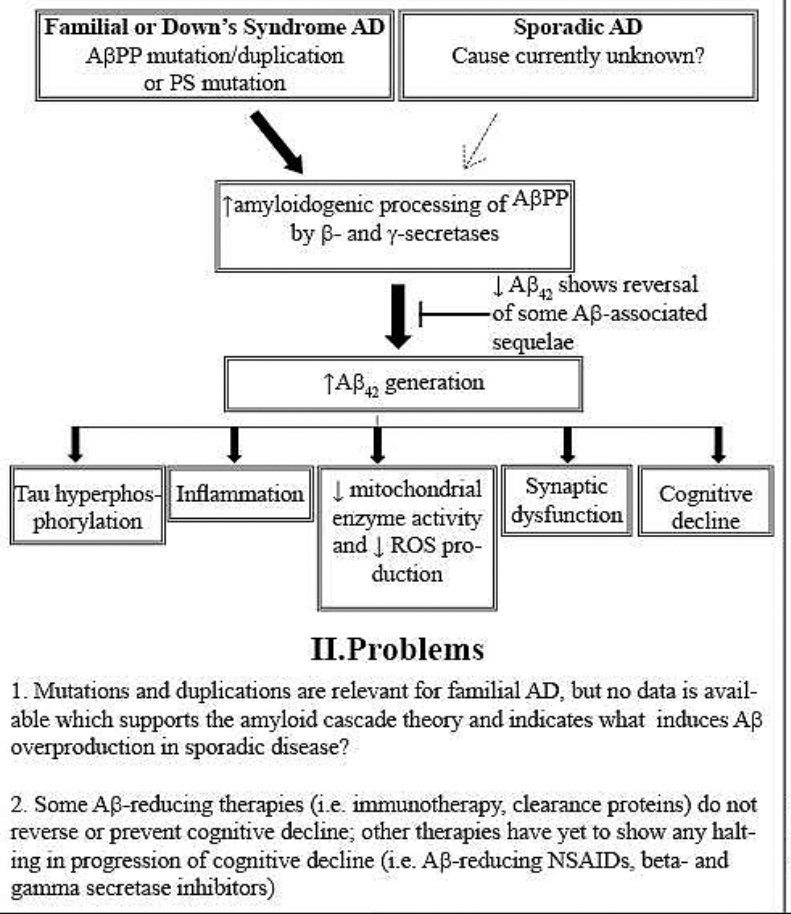

Mitochondrial Cascade Hypothesis I. Mechanism

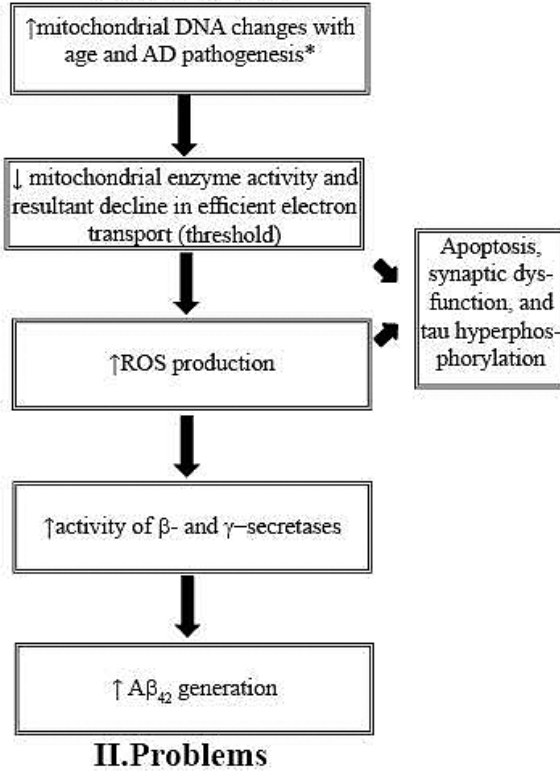

1. *Lack of identification of specific mtDNA mutations and deletions associated with sporadic $\mathrm{AD}$; however, other mechanisms or heterogeneity in mitochondrial alterations may be involved.

Fig. 1. Amyloid Cascade Hypothesis versus Mitochondrial Cascade Hypothesis. Hardy and Higgins [9] proposed increased A $\beta$ as the causative agent for AD pathogenesis; supporting data from overexpression or mutation models in animals and cells supports that $\mathrm{A} \beta$ can induce these pathologies. However, though the expression of mutated proteins only proves $\mathrm{A} \beta$ can cause these sequelae, it does not prove that it is the underlying cause in the majority of cases (i.e., sporadic disease). Swerdlow and Khan [123,196] proposed mitochondrial inheritance determines mitochondrial function and response to aging. The mitochondrial cascade hypothesis suggests that in sporadic AD, mitochondrial alterations acquired over time reach a disease "threshold," at which mitochondrial dysfunction ensues, oxidative stress increases, and other AD pathology develops (i.e., $\mathrm{A} \beta$ overproduction, tau hyperphosphorylation/aggregation, synaptic dysfunction, and cell death).

toxic to an already-damaged organelle? $\gamma$-secretase is known to cleave a number of transmembrane proteins, so its rise in activity could easily be due to its roles in the cleavage of another protein. In a seemingly unrelated disease CADASIL (cerebral autosomal dominate arteriopathy with subcortical infarcts and leukoencephalopathy), mutations in NOTCH3 appear to have a negative effect on mitochondrial function, causing structural abnormalities and decrease complex I and V activities $[174,175]$. These changes in mitochondrial function may be secondary to another feature of the disease, which has not been uncovered yet. The likelihood that Notch processing is altered in AD is unlikely at this time because a role for Notch has not been identified, and Notch has been localized only to the plasma membrane, not the mitochondria. However, the heterogeneity of $\gamma$-secretase in processing proteins for physiological functions increases the likelihood that additional targets other than $\mathrm{A} \beta \mathrm{PP}$, Notch, and E-cadherin may exist that could be related to mitochondrial structure and function.

\section{$\gamma$-secretase in mitochondria}

To begin considering the relationship of secretase enzymes to mitochondrial function, increases in oxidative stress, and their AD-relevant target protein $\mathrm{A} \beta \mathrm{PP}$, it is important to review what is already known about $\gamma$-secretase in mitochondria and how it relates to both the amyloid and mitochondrial hypotheses. Understanding how secretase enzymes are related to mitochondrial dysfunction in AD will provide greater understanding towards their potential use as therapeutic targets. The catalytically active components of $\gamma$ secretase have been identified in the plasma membrane, Golgi, endoplasmic reticulum, and mitochondria [176, 177]. The presence of $\gamma$-secretase within mitochondria suggests one or more its targets must be also present 
there. To date, its other known targets (i.e., Notch, p75NTR, ErbB-4, and E-cadherin) have not been reported in the mitochondria, but full-length $\mathrm{A} \beta \mathrm{PP}$ has been shown to accumulate in the import channels of the inner and outer mitochondrial membranes in AD brains only and is associated with increased oxidative stress and reduced cytochrome oxidase activity [147, 178]. This AD-related reduction in mitochondrial function is presumed to be due to the inhibition of the entry of nuclear-encoded ETC proteins. Studies also allude to direct access of the mitochondrial compartment to mitochondria-generated $\mathrm{A} \beta$. $\mathrm{A} \beta \mathrm{PP}$ accumulation in the mitochondria may be increased to generate higher levels of $\mathrm{A} \beta_{40}$, which evolving evidence suggests may have neuroprotective properties [179]. Provided $A \beta_{40}$ does have a neuroprotective role, then mitochondrial $\gamma$ secretase activity may be triggered to increase the cells' $\mathrm{A} \beta_{40}$ store, but not selective enough to prevent increases in levels $\mathrm{A} \beta_{42}$ in mitochondria. The mechanism for increasing $\mathrm{A} \beta_{42}$ levels in familial cases with $\mathrm{A} \beta \mathrm{PP}$ mutations is understood to be through an altered conformation of PS 1 and PS 2 when binding to $\mathrm{A} \beta \mathrm{PP}$. If $\mathrm{A} \beta \mathrm{PP}$ processing within mitochondria is increased to provide $\mathrm{A} \beta_{40}$-dependent neuroprotection to an ailing organelle, understanding how $\gamma$-secretase cleavage specificity of $\mathrm{A} \beta \mathrm{PP}$ in $\mathrm{sAD}$ occurs is important to identifying why $\mathrm{A} \beta \mathrm{PP}$ accumulation and $\gamma$-secretase activity increases in mitochondria go awry and lead to toxic products or identifying effective therapies for increasing neuroprotective $\mathrm{A} \beta_{40}$ versus neurotoxic $\mathrm{A} \beta_{42}[27,180]$. This inability of $\gamma$-secretase cleavage to be selective for production of a neuroprotective amyloid peptide suggests an alternative purpose for $\gamma$-secretase activity within mitochondria: whether this enzyme is present simply for the generation of $\mathrm{A} \beta$, which is shown to be extremely toxic to mitochondrial proteins, or for another physiological role within mitochondria? To date, no evidence of $\beta$-secretase activity within the mitochondrial compartment has been reported. Instead, $\beta$-secretase activity appears to be confined to lipid rafts within the plasma membrane [181], suggesting A $\beta$ generation may be confined to this area of the cell or $\mathrm{sA} \beta \mathrm{PP} \beta$ may be imported into mitochondria to be further cleaved by $\gamma$-secretase. In the meantime, this current lack of evidence for $\beta$-secretase activity within the mitochondria leaves an unanswered question of whether $\mathrm{A} \beta$ is generated within mitochondria and what is the purpose of ubiquitous expression of $\gamma$-secretase, specifically for the mitochondria. In addition, it is unknown whether any mitochondria-related events are affected by mutations or deletions in $\gamma$-secretase components, just as alterations of enzyme activity may affect Notch and E-cadherin cleavage [182].

In line with the amyloid cascade hypothesis is the theory that $\mathrm{A} \beta$ through unknown, but highly debated, mechanisms accumulates in the mitochondria, increasing the possibility of direct contact with mitochondrial enzymes [146,148,180] as a competitive or noncompetitive inhibitor of enzyme assembly and/or function. However, the existence of mitochondrial dysfunction at an early stage of AD development in mouse models poses some questions as to whether or not this is the main route of mitochondrial toxicity in $\mathrm{AD}$. While the initiating event for AD pathology is unclear, it is evident that mtDNA mutations, $\mathrm{A} \beta$ overproduction, protein misassembly/reduced activity, and mitochondrial dysfunction may all play a role, either independent or dependent of one another. Regardless of the mechanism for mitochondrial dysfunction in $\mathrm{AD}$, it is clear that AD pathogenesis is in part caused by dramatic increases in oxidative stress, which further deteriorates mitochondrial function and provides increases in $\mathrm{A} \beta$ generation.

\section{Disease-modifying anti-Alzheimer's drugs (DMAAD) and mitochondria}

To date, the development of DMAADs for $\mathrm{SAD}$ relies heavily on the amyloid cascade hypothesis and little work has been published as to the effect of these $\mathrm{A} \beta$ reducing agents on mitochondrial respiratory function. Since there is much evidence for the development of sAD from an etiology based mostly on mitochondrial dysfunction, it is imperative that we determine what therapies may have a positive effect on mitochondrial function.

The finding of increased oxidative stress in $\mathrm{AD}$ brains has certainly been an enigma in the study of AD. On one hand, oxidative stress leads to downstream increases in $\mathrm{A} \beta$-producing enzyme activity, specifically through increased BACE1 activity and presenilin 1 levels $[166,167]$. On the other hand, the presence of $\mathrm{A} \beta$ leads to increased generation of ROS, therefore puzzling researchers with the question of which pathology arose first in cases of sporadic AD. There has been much evidence for increased ROS due to age-related problems with bioenergetics, specifically reductions in glucose metabolism and ETC enzyme activity. Clinical relevance for targeting reduced mitochondrial function and increased oxidative stress is stronger than that for blocking $\mathrm{A} \beta$ generation or increasing its clearance because of the existence of data depicting potential 
signs of dysfunction at a preclinical stage. The logical step for therapeutics is to identify drugs that prevent ROS production or scavenge ROS, in hopes of halting the progression of the disease. It is thought that the scavenging of free radicals by antioxidants could decrease some of the resultant pathology and prevent further decline in cognitive function. The antioxidant tricyclodecan-9-yl xanthogenate demonstrated the ability to protect against oxidative stress induced by $\mathrm{A} \beta$ [183]. In addition, Jayaprakasam and others reported the protection of rat neuronal cells from cell death by withanamides [184]. The antioxidant properties of these drugs were demonstrated in conjunction with $\mathrm{A} \beta_{42}$ toxicity, but they may prove useful in counteracting the endogenous oxidative stress generated in elderly non-demented and AD individuals. Since oxidative stress can lead to apoptosis and exists in MCI and AD, the use of antioxidants as a therapy is warranted. However, at this time, the effects of long-term antioxidant use in AD patients still remains to be known [147] and may later be overcome by the mechanism responsible for overproducing ROS.

Since $\mathrm{A} \beta$ is known to lead to a number of $\mathrm{AD}$ pathologies, i.e., tau hyperphosphorylation, synaptic and cholinergic dysfunction, and oxidative stress, many continue to study therapies that can affect AD pathogenesis at this level. Since the earliest time-point is still debated, the major target is at the level of $\mathrm{A} \beta$ production through the inhibition of $\mathrm{A} \beta \mathrm{PP}$-cleavage enzymes $\beta$ and $\gamma$-secretases. Though these may prove promising by halting the development of tau tangles and synaptic dysfunction, a major area of investigation left unstudied is whether the mitochondrial impairments caused by $\mathrm{A} \beta$ overproduction, aggregation, and accumulation are reversible. In addition, though currently available data shows some promise for secretase-inhibiting therapy, it is important to consider a report of immunotherapyassociated clearance of amyloid plaques without improvement in disease progression or survival [185], even though immune therapy was previously shown to reduce A $\beta$ levels [33,186-189]. Additionally, while the overexpression of neprilysin, an $\mathrm{A} \beta$-degrading enzyme, reduces $\mathrm{A} \beta$ levels by $50 \%$, it did not improve impairments in spatial learning and memory in transgenic mice [190]. As previously stated, NSAIDs with A $\beta$-reducing ability do not demonstrate greater protective ability compared to NSAIDs without $\mathrm{A} \beta$-reducing ability [114]. In addition, AD subjects treated with NSAIDs and cholinesterase inhibitors appear to only have short-term protection from the development of $\mathrm{AD}$, thereby suggesting these drugs only serve a symp- tomatic purpose, which may be unrelated to their $\mathrm{A} \beta$ reducing activities. In context with these recent reports, this places further doubt that lowering $\mathrm{A} \beta$ actually prevents progressive neurodegeneration. These studies suggest that $\mathrm{A} \beta$ overproduction is not directly responsible for cognitive decline as the amyloid cascade theory states and indicates that additional studies for a pathological marker of cognitive decline are needed.

Clinical trials for $\beta$ - and $\gamma$-secretase inhibitors are next in line for data showing a positive effect on cognitive function. To date, no final reports of their long-term efficacy have been provided. Currently, the animal data suggests cognition will benefit from GSI use [25], but the immune therapy also demonstrated similar results when working with mouse models. Another pitfall of the pre-clinical work from these studies is a lack of observation for their effects on mitochondrial function. Since data supporting the mitochondrial cascade theory shows us that mitochondrial impairments and oxidative stress occur earlier than $\mathrm{A} \beta$ deposition; $\gamma$-secretase and $\mathrm{A} \beta \mathrm{PP}$ within the mitochondria provide direct access for generated $\mathrm{A} \beta ; \gamma$-secretase and $\beta$-secretase activities are linked to oxidative stress levels; and $\mathrm{A} \beta$ generated outside the mitochondria may be transported into the organelle, data for the effect of secretase inhibitors on mitochondria is absolutely necessary. Those studies that do report improvements in mitochondrial function (i.e., mitochondrial membrane potential) have only been performed in cell or animal models with overexpressed or mutated proteins [26], which is representative of familial $\mathrm{AD}$ and not sporadic. In an attempt to determine if secretase inhibitors could in fact recover mitochondrial function as the amyloid cascade theory suggests, we treated a sAD-phenotypic cell line with commercially available $\beta$ - and $\gamma$-secretase inhibitors and measured mitochondrial function. When we began our work, we speculated based on the available data and the amyloid cascade theory that secretase inhibitors would either restore proper mitochondrial function or have no effect if $\mathrm{A} \beta$ was not directly responsible for this drop in mitochondrial function (or its effects were irreversible). Surprisingly, initial results from our laboratory demonstrated additional impairments in mitochondrial bioenergetics after $\gamma$-secretase inhibitor treatment of a cell line with an established AD phenotype. This preliminary data raises questions as to the effectiveness of all $\gamma$-secretase inhibitors and whether or not this decline in mitochondrial function would extend to clinical side effects, especially in a population already observed to have reduced mitochondrial function. 
We hypothesize that the decline in mitochondrial function could be due to one of two possibilities. First, some $\mathrm{A} \beta$ peptides, which are all reduced with nonspecific $\gamma$-secretase treatment, may actually prove critical to normal mitochondrial and neuronal function; and secondly, since this decline was also observed in the control lines under the same treatment conditions, $\gamma$ secretase may serve a role in regulating mitochondrial respiration, which is inhibited with the use of GSIs. Evidence supporting the first possibility includes the ability of $\mathrm{A} \beta_{40}$ to rescue neuronal cells lines from secretase inhibitor-induced cell death [179]. Only this size peptide was useful in rescuing the viability phenotype. However, it is still necessary to determine what other alterations in cellular or mitochondrial function are observed with a decline in viability. If a decline in mitochondrial function is associated with the cell death observed, improvement of mitochondrial function or no change could be obtained by treating cells with $\mathrm{A} \beta_{40}$ along with the inhibitor therapy. However, additional data from our laboratory (Young and Bennett, unpublished data) treating cells and isolated brain mitochondria suggests that the inhibition of $\gamma$-secretase further deteriorates mitochondrial function in a non- $\mathrm{A} \beta$ dependent manner. Acute $\gamma$-secretase treatment was able to replicate the decline in mitochondrial respiration over 30-40 min, and this abrupt change cannot be accounted for by the absence of $\mathrm{A} \beta \mathrm{PP}$, Notch, or E-cadherin cleavage (unpublished data). This supports the second possibility: $\gamma$-secretase may have a role in mitochondrial function.

Supporting evidence for a secondary $\gamma$-secretase role comes from conflicting ideas about the relationship between $\gamma$-secretase and the neurodegeneration seen in AD. According to the amyloid cascade hypothesis, as previously mentioned, $\gamma$-secretase mutations lead a gain in function that leads to increased $\mathrm{A} \beta$ production and downstream neurodegeneration. However, loss of PS function can also result in hyperphosphorylated tau, synaptic dysfunction, neurodegeneration, and memory impairments [105]. As would be expected in cells lacking PS activity, no $\mathrm{A} \beta$ should be produced, generating additional questions about how an alteration of $\gamma$ secretase activity relates to other pathological features of $\mathrm{AD}$.

\section{CONCLUSION AND FUTURE PERSPECTIVES}

Moving forward, the field would benefit from an identification of which forms of the $\gamma$-secretase com- plexes are in greatest abundance in mitochondria and for which substrates they have a greater affinity. It is possible that the ratio of $\gamma$-secretase complex makeup within the mitochondria differs from that at the level of the plasma membrane and may mediate different processes other than cleavage of the previously mentioned $\gamma$-secretase targets. The secretase enzymes appear to have numerous protein targets, such as with BACE1 and BACE2's recent identification in cleavage of pancreatic enteropeptidases and in mediating increased anxiety in mice [191,192]. However, the location of $\gamma$-secretase is specifically important to identifying additional protein targets, since no targets other than $\mathrm{A} \beta \mathrm{PP}$ have been identified in this organelle, and its role in A $\beta \mathrm{PP}$ cleavage appears to be additive in $\mathrm{AD}$ development. Our preliminary data suggests a role in respiration, and we support the further study of this enzyme in maintaining normal mitochondrial function and alleviating problems. Based on the preliminary data in our laboratory, $\gamma$-secretase may likely have a role in mitochondrial respiration. This idea is not far-fetched, since a link between $\gamma$-secretase expression/activity and oxidative stress has already been established. One possibility is that $\gamma$-secretase may exert a protective effect for mitochondrial bioenergetics, leading to upregulation of the enzyme when the organelle is under greater oxidative stress. Inhibition of this enzyme could remove the normal regulatory ability $\gamma$-secretase has in respiration or may be toxic to an organelle already being damaged by the initiating event that has led to $\mathrm{A} \beta$ overproduction, mitochondrial dysfunction, and oxidative stress. The sequence requirement for and site of substrate cleavage differs for each substrate, suggesting other members of the complex or other cellular components are responsible for regulating which substrates are cleaved by PS. The ability of the $\gamma$-secretase complex to arrange in six distinct varieties might facilitate this regulation in different environments. In addition, the promiscuous nature of $\gamma$-secretase and the growing number of transmembrane proteins targeted by $\gamma$-secretase suggest that additional substrates may exist. In line with our unpublished data, we propose an additional substrate(s) may exist within the mitochondrial compartment and be involved in the regulation of normal mitochondrial respiration (Fig. 2). The identification of a mitochondrial protein cleaved by $\gamma$-secretase may possess cleavage features similar to those of A $\beta$ PP, Notch, ErbB4, Ecadherin, and p75NTR: 1) prior cleavage by ADAM10 or another $\alpha$-secretase [193]; 2) dependency of pre$\alpha$-secretase cleavage on distance of protein residues from membrane; and 3 ) intramembraneous cleavage by 


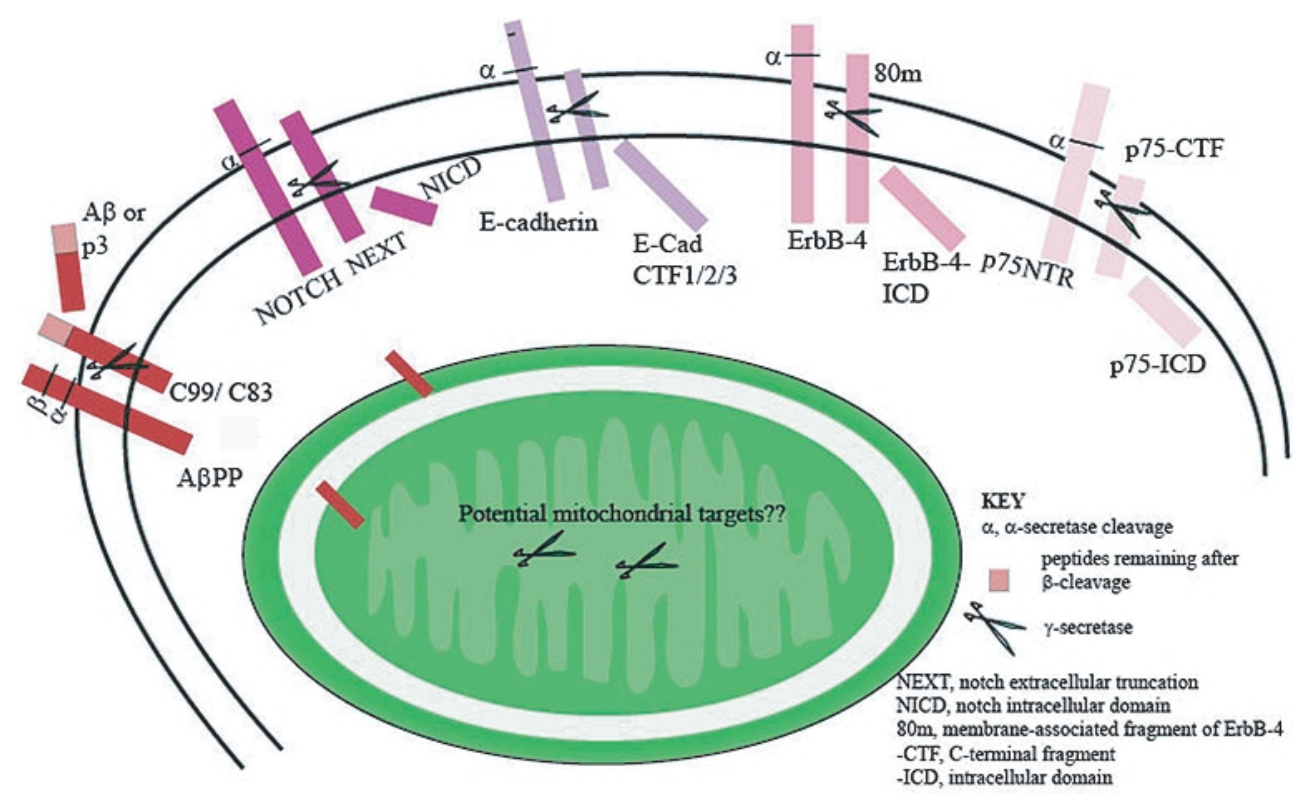

Fig. 2. $\gamma$-secretase targets in plasma membrane and potential role in mitochondria. The transmembrane proteins A $\beta$ PP, Notch, E-cadherin, ErbB-4, and p75NTR [80,194,197] are targets of $\gamma$-secretase cleavage. Each protein first undergoes $\alpha$-secretase cleavage of their ectodomain by a metalloprotease (e.g., ADAM10, TACE), followed by $\gamma$-secretase-mediated cleavage at multiple sites within the transmembrane domain. These products of $\gamma$-secretase cleavage are usually targeted to the nucleus. Currently, A $\beta \mathrm{PP}$ is the only known target that is also localized to the mitochondria. Enzymatically active $\gamma$-secretase is found within the mitochondrial matrix, suggesting that $\gamma$-secretase may lead to cleavage of mitochondrial $\mathrm{A} \beta \mathrm{PP}$, though no data implicating $\beta$-secretase activity within mitochondria has been reported. However, unpublished data from our laboratory suggests $\gamma$-secretase could also serve additional, but currently unknown roles in mitochondrial function.

$\gamma$-secretase, though in this case, it would be within a mitochondrial membrane instead of the plasma membrane $[80,82,83,193-195]$.

There is no doubt that $\mathrm{A} \beta$ can cause $\mathrm{AD}$-related impairments, including reductions in ETC protein activity. On the same note, it is also apparent that reductions in $\mathrm{A} \beta$ can rescue $\mathrm{AD}$-related pathologies in cell or animal models with pathologies due to this source. Animal models have been used extensively in AD research, specifically in the recapitulation of AD pathology and rescue through overexpression and mutation models. Though no one will argue that $\mathrm{A} \beta$ overproduction will cause most pathologies already discussed, as in familial AD and animal models, there is still doubt that $\mathrm{A} \beta$ is the main cause or initiating event of the same pathologies observed in sporadic cases. Therefore, in sporadic $\mathrm{AD}$, where $\mathrm{A} \beta$ does not appear to be the underlying cause, preventing or reversing these impairments may prove much more difficult without a greater understanding of the etiology of the impairment, the impairments themselves, and the degree of reversibility that exists. Mitochondrial impairment appears to be a more probable cause for the AD pathogenesis, through the mechanisms proposed in the mitochondrial cascade theory. In addition, it appears that though $\gamma$-secretase is traditionally studied for its role in $\mathrm{A} \beta$ generation, it may prove useful to understand its additional and more AD-relevant roles in mitochondrial function.

\section{ACKNOWLEDGMENTS}

Supported by NS39788, AG023443, National Institute of Mental Health-PMRTP, and the D. Loy Stewart Research Fund. We thank Dr. Shilpa Iyer for critical reading of the manuscript and for graphic design assistance for Fig. 2.

Authors' disclosures available online (http://www.jalz.com/disclosures/view.php?id=387).

\section{REFERENCES}

[1] Simon RP, Greenberg D, Aminoff MJ (2009) Clinical Neurology, 7 edition. The McGraw-Hill Companies, Inc., United States of America.

[2] Rowland LP (2005) Merritt's Neurology. Lippincott Williams \& Wilkins, United States of America. 
[3] Hirai K, Aliev G, Nunomura A, Fujioka H, Russell RL, Atwood CS, Johnson AB, Kress Y, Vinters HV, Tabaton M, Shimohama S, Cash AD, Siedlak SL, Harris PL, Jones PK, Petersen RB, Perry G, Smith MA (2001) Mitochondrial abnormalities in Alzheimer's disease. J Neurosci 21, 3017-3023.

[4] Rogers J, Webster S, Lue LF, Brachova L, Civin WH, Emmerling M, Shivers B, Walker D, McGeer P (1996) Inflammation and Alzheimer's disease pathogenesis. Neurobiol Aging $\mathbf{1 7}$ 681-686.

[5] Davies P, Maloney AJ (1976) Selective loss of central cholinergic neurons in Alzheimer's disease. Lancet 2, 1403.

[6] Kasa P, Rakonczay Z, Gulya K (1997) The cholinergic system in Alzheimer's disease. Prog Neurobiol 52, 511-535.

[7] Masliah E, Hansen L, Albright T, Mallory M, Terry RD (1991) Immunoelectron microscopic study of synaptic pathology in Alzheimer's disease. Acta Neuropathol 81, 428433.

[8] Scheff SW, Price DA (2003) Synaptic pathology in Alzheimer's disease: a review of ultrastructural studies. $\mathrm{Neu}$ robiol Aging 24, 1029-1046.

[9] Hardy JA, Higgins GA (1992) Alzheimer's disease: the amyloid cascade hypothesis. Science 256, 184-185.

[10] Citron M, Oltersdorf T, Haass C, McConlogue L, Hung AY, Seubert P, Vigo-Pelfrey C, Lieberburg I, Selkoe DJ (1992) Mutation of the beta-amyloid precursor protein in familial Alzheimer's disease increases beta-protein production. $\mathrm{Na}$ ture 360, 672-674.

[11] Goate A, Chartier-Harlin MC, Mullan M, Brown J, Crawford F, Fidani L, Giuffra L, Haynes A, Irving N, James L, et al. (1991) Segregation of a missense mutation in the amyloid precursor protein gene with familial Alzheimer's disease. Nature 349, 704-706.

[12] Tyrrell J, Cosgrave M, McCarron M, McPherson J, Calvert J, Kelly A, McLaughlin M, Gill M, Lawlor BA (2001) Dementia in people with Down's syndrome. Int J Geriatr Psychiatry 16, 1168-1174

[13] Schupf N, Patel B, Silverman W, Zigman WB, Zhong N, Tycko B, Mehta PD, Mayeux R (2001) Elevated plasma amyloid beta-peptide 1-42 and onset of dementia in adults with Down syndrome. Neurosci Lett 301, 199-203.

[14] Zheng WH, Bastianetto S, Mennicken F, Ma W, Kar S (2002) Amyloid beta peptide induces tau phosphorylation and loss of cholinergic neurons in rat primary septal cultures. Neuroscience 115, 201-211.

[15] De Felice FG, Wu D, Lambert MP, Fernandez SJ, Velasco PT, Lacor PN, Bigio EH, Jerecic J, Acton PJ, Shughrue PJ, Chen-Dodson E, Kinney GG, Klein WL (2008) Alzheimer's disease-type neuronal tau hyperphosphorylation induced by A beta oligomers. Neurobiol Aging 29, 1334-1347.

[16] Meda L, Cassatella MA, Szendrei GI, Otvos L, Jr., Baron P, Villalba M, Ferrari D, Rossi F (1995) Activation of microglial cells by beta-amyloid protein and interferon-gamma. Nature 374, 647-650.

[17] Butterfield DA (2002) Amyloid beta-peptide (1-42)-induced oxidative stress and neurotoxicity: implications for neurodegeneration in Alzheimer's disease brain. A review. Free Radic Res 36, 1307-1313.

[18] Hsiao K, Chapman P, Nilsen S, Eckman C, Harigaya Y, Younkin S, Yang F, Cole G (1996) Correlative memory deficits, Abeta elevation, and amyloid plaques in transgenic mice. Science 274, 99-102.

[19] Radde R, Bolmont T, Kaeser SA, Coomaraswamy J, Lindau D, Stoltze L, Calhoun ME, Jaggi F, Wolburg H, Gengler S, Haass C, Ghetti B, Czech C, Holscher C, Mathews PM, Juck- er M (2006) Abeta42-driven cerebral amyloidosis in transgenic mice reveals early and robust pathology. EMBO Rep 7, 940-946.

[20] Shankar GM, Li S, Mehta TH, Garcia-Munoz A, Shepardson NE, Smith I, Brett FM, Farrell MA, Rowan MJ, Lemere CA, Regan CM, Walsh DM, Sabatini BL, Selkoe DJ (2008) Amyloid-beta protein dimers isolated directly from Alzheimer's brains impair synaptic plasticity and memory. Nat Med 14, 837-842.

[21] Townsend M, Shankar GM, Mehta T, Walsh DM, Selkoe DJ (2006) Effects of secreted oligomers of amyloid beta-protein on hippocampal synaptic plasticity: a potent role for trimers. J Physiol 572, 477-492.

[22] Walsh DM, Klyubin I, Fadeeva JV, Cullen WK, Anwyl R, Wolfe MS, Rowan MJ, Selkoe DJ (2002) Naturally secreted oligomers of amyloid beta protein potently inhibit hippocampal long-term potentiation in vivo. Nature 416, 535-539.

[23] Dovey HF, John V, Anderson JP, Chen LZ, de Saint Andrieu P, Fang LY, Freedman SB, Folmer B, Goldbach E, Holsztynska EJ, Hu KL, Johnson-Wood KL, Kennedy SL, Kholodenko D, Knops JE, Latimer LH, Lee M, Liao Z, Lieberburg IM, Motter RN, Mutter LC, Nietz J, Quinn KP, Sacchi KL, Seubert PA, Shopp GM, Thorsett ED, Tung JS, Wu J, Yang S, Yin CT, Schenk DB, May PC, Altstiel LD, Bender MH, Boggs LN, Britton TC, Clemens JC, Czilli DL, Dieckman-McGinty DK, Droste JJ, Fuson KS, Gitter BD, Hyslop PA, Johnstone EM, Li WY, Little SP, Mabry TE, Miller FD, Audia JE (2001) Functional gamma-secretase inhibitors reduce beta-amyloid peptide levels in brain. J Neurochem 76, 173-181.

[24] Imbimbo BP (2009) An update on the efficacy of nonsteroidal anti-inflammatory drugs in Alzheimer's disease. $E x$ pert Opin Investig Drugs 18, 1147-1168.

[25] Comery TA, Martone RL, Aschmies S, Atchison KP, Diamantidis G, Gong X, Zhou H, Kreft AF, Pangalos MN, Sonnenberg-Reines J, Jacobsen JS, Marquis KL (2005) Acute gamma-secretase inhibition improves contextual fear conditioning in the $\mathrm{Tg} 2576$ mouse model of Alzheimer's disease. J Neurosci 25, 8898-8902.

[26] Sheng B, Gong K, Niu Y, Liu L, Yan Y, Lu G, Zhang L, Hu M, Zhao N, Zhang X, Tang P, Gong Y (2009) Inhibition of gamma-secretase activity reduces Abeta production, reduces oxidative stress, increases mitochondrial activity and leads to reduced vulnerability to apoptosis: Implications for the treatment of Alzheimer's disease. Free Radic Biol Med 46, 1362-1375.

[27] Anandatheerthavarada HK, Biswas G, Robin MA, Avadhani NG (2003) Mitochondrial targeting and a novel transmembrane arrest of Alzheimer's amyloid precursor protein impairs mitochondrial function in neuronal cells. J Cell Biol 161, 41-54.

[28] Sambamurti K, Refolo LM, Shioi J, Pappolla MA, Robakis NK (1992) The Alzheimer's amyloid precursor is cleaved intracellularly in the trans-Golgi network or in a post-Golgi compartment. Ann N Y Acad Sci 674, 118-128.

[29] Priller C, Bauer T, Mitteregger G, Krebs B, Kretzschmar HA, Herms J (2006) Synapse formation and function is modulated by the amyloid precursor protein. J Neurosci 26, 7212-7221.

[30] Zheng H, Koo EH (2006) The amyloid precursor protein: beyond amyloid. Mol Neurodegener 1, 5.

[31] Moir RD, Lynch T, Bush AI, Whyte S, Henry A, Portbury S, Multhaup G, Small DH, Tanzi RE, Beyreuther K, Masters CL (1998) Relative increase in Alzheimer's disease of soluble forms of cerebral Abeta amyloid protein precursor containing 
the Kunitz protease inhibitory domain. J Biol Chem 273, 5013-5019.

[32] Matsui T, Ingelsson M, Fukumoto H, Ramasamy K, Kowa H, Frosch MP, Irizarry MC, Hyman BT (2007) Expression of APP pathway mRNAs and proteins in Alzheimer's disease. Brain Res 1161, 116-123.

[33] Rosenberg RN, Baskin F, Fosmire JA, Risser R, Adams P, Svetlik D, Honig LS, Cullum CM, Weiner MF (1997) Altered amyloid protein processing in platelets of patients with Alzheimer disease. Arch Neurol 54, 139-144.

[34] Di Luca M, Pastorino L, Cattabeni F, Zanardi R, Scarone S, Racagni G, Smeraldi E, Perez J (1996) Abnormal pattern of platelet APP isoforms in Alzheimer disease and Down syndrome. Arch Neurol 53, 1162-1166.

[35] Di Luca M, Pastorino L, Bianchetti A, Perez J, Vignolo LA, Lenzi GL, Trabucchi M, Cattabeni F, Padovani A (1998) Differential level of platelet amyloid beta precursor protein isoforms: an early marker for Alzheimer disease. Arch Neurol 55, 1195-1200.

[36] Haass C, Hung AY, Schlossmacher MG, Teplow DB, Selkoe DJ (1993) beta-Amyloid peptide and a 3-kDa fragment are derived by distinct cellular mechanisms. J Biol Chem $\mathbf{2 6 8}$, 3021-3024.

[37] Kowalska A (2004) Genetic basis of neurodegeneration in familial Alzheimer's disease. Pol J Pharmacol 56, 171-178.

[38] Suzuki N, Cheung TT, Cai XD, Odaka A, Otvos L, Jr., Eckman C, Golde TE, Younkin SG (1994) An increased percentage of long amyloid beta protein secreted by familial amyloid beta protein precursor (beta APP717) mutants. Science 264, 1336-1340.

[39] Roher AE, Lowenson JD, Clarke S, Woods AS, Cotter RJ, Gowing E, Ball MJ (1993) beta-Amyloid-(1-42) is a major component of cerebrovascular amyloid deposits: implications for the pathology of Alzheimer disease. Proc Natl Acad Sci U S A 90, 10836-10840.

[40] Herl L, Thomas AV, Lill CM, Banks M, Deng A, Jones PB, Spoelgen R, Hyman BT, Berezovska O (2009) Mutations in amyloid precursor protein affect its interactions with presenilin/gamma-secretase. Mol Cell Neurosci 41, 166-174.

[41] Bitan G, Kirkitadze MD, Lomakin A, Vollers SS, Benedek GB, Teplow DB (2003) Amyloid beta -protein (Abeta) assembly: Abeta 40 and Abeta 42 oligomerize through distinct pathways. Proc Natl Acad Sci U S A 100, 330-335.

[42] Burdick D, Soreghan B, Kwon M, Kosmoski J, Knauer M, Henschen A, Yates J, Cotman C, Glabe C (1992) Assembly and aggregation properties of synthetic Alzheimer's A4/beta amyloid peptide analogs. J Biol Chem 267, 546-554.

[43] Irie K, Murakami K, Masuda Y, Morimoto A, Ohigashi H, Ohashi R, Takegoshi K, Nagao M, Shimizu T, Shirasawa $\mathrm{T}$ (2005) Structure of beta-amyloid fibrils and its relevance to their neurotoxicity: implications for the pathogenesis of Alzheimer's disease. J Biosci Bioeng 99, 437-447.

[44] Mucke L, Masliah E, Yu GQ, Mallory M, Rockenstein EM, Tatsuno G, Hu K, Kholodenko D, Johnson-Wood K, McConlogue L (2000) High-level neuronal expression of abeta 1-42 in wild-type human amyloid protein precursor transgenic mice: synaptotoxicity without plaque formation. $J$ Neurosci 20, 4050-4058.

[45] Iwatsubo T, Odaka A, Suzuki N, Mizusawa H, Nukina N, Ihara Y (1994) Visualization of A beta 42(43) and A beta 40 in senile plaques with end-specific A beta monoclonals: evidence that an initially deposited species is A beta 42(43). Neuron 13, 45-53.
[46] Berg L, McKeel DW, Jr., Miller JP, Storandt M, Rubin EH, Morris JC, Baty J, Coats M, Norton J, Goate AM, Price JL, Gearing M, Mirra SS, Saunders AM (1998) Clinicopathologic studies in cognitively healthy aging and Alzheimer's disease: relation of histologic markers to dementia severity, age, sex, and apolipoprotein E genotype. Arch Neurol 55, 326-335.

[47] Sloane JA, Pietropaolo MF, Rosene DL, Moss MB, Peters A, Kemper T, Abraham CR (1997) Lack of correlation between plaque burden and cognition in the aged monkey. Acta Neuropathol 94, 471-478.

[48] Casley CS, Canevari L, Land JM, Clark JB, Sharpe MA (2002) Beta-amyloid inhibits integrated mitochondrial respiration and key enzyme activities. J Neurochem 80, 91-100.

[49] Dahlgren KN, Manelli AM, Stine WB, Jr., Baker LK, Krafft GA, LaDu MJ (2002) Oligomeric and fibrillar species of amyloid-beta peptides differentially affect neuronal viability. J Biol Chem 277, 32046-32053.

[50] Demuro A, Mina E, Kayed R, Milton SC, Parker I, Glabe CG (2005) Calcium dysregulation and membrane disruption as a ubiquitous neurotoxic mechanism of soluble amyloid oligomers. J Biol Chem 280, 17294-17300.

[51] Kim HJ, Chae SC, Lee DK, Chromy B, Lee SC, Park YC, Klein WL, Krafft GA, Hong ST (2003) Selective neuronal degeneration induced by soluble oligomeric amyloid beta protein. FASEB J 17, 118-120.

[52] Tabner BJ, Turnbull S, El-Agnaf O, Allsop D (2001) Production of reactive oxygen species from aggregating proteins implicated in Alzheimer's disease, Parkinson's disease and other neurodegenerative diseases. Curr Top Med Chem 1 , 507-517.

[53] Hussain I, Powell D, Howlett DR, Tew DG, Meek TD, Chapman C, Gloger IS, Murphy KE, Southan CD, Ryan DM, Smith TS, Simmons DL, Walsh FS, Dingwall C, Christie G (1999) Identification of a novel aspartic protease (Asp 2) as beta-secretase. Mol Cell Neurosci 14, 419-427.

[54] Fukumoto H, Cheung BS, Hyman BT, Irizarry MC (2002) Beta-secretase protein and activity are increased in the neocortex in Alzheimer disease. Arch Neurol 59, 1381-1389.

[55] Holsinger RM, McLean CA, Beyreuther K, Masters CL, Evin $\mathrm{G}$ (2002) Increased expression of the amyloid precursor betasecretase in Alzheimer's disease. Ann Neurol 51, 783-786.

[56] Devi L, Ohno M (2010) Genetic reductions of beta-site amyloid precursor protein-cleaving enzyme 1 and amyloid-beta ameliorate impairment of conditioned taste aversion memory in 5XFAD Alzheimer's disease model mice. Eur J Neurosci 31, 110-118.

[57] Kimura R, Devi L, Ohno M (2010) Partial reduction of BACE1 improves synaptic plasticity, recent and remote memories in Alzheimer's disease transgenic mice. J Neurochem, in press.

[58] McConlogue L, Buttini M, Anderson JP, Brigham EF, Chen KS, Freedman SB, Games D, Johnson-Wood K, Lee M, Zeller M, Liu W, Motter R, Sinha S (2007) Partial reduction of BACE1 has dramatic effects on Alzheimer plaque and synaptic pathology in APP Transgenic Mice. J Biol Chem 282, 26326-26334.

[59] Ghosh AK, Gemma S, Tang J (2008) beta-Secretase as a therapeutic target for Alzheimer's disease. Neurotherapeutics 5, 399-408.

[60] Niu Y, Wang Y, Zou X, Yang X, Ma C, Lu Y, Zhou B, Yuan Y, Du G, Xu P (2010) Synthesis and preliminary evaluation of peptidomimetic inhibitors of human beta-secretase. Eur J Med Chem 45, 2089-2094. 
[61] Perez RG, Zheng H, Van der Ploeg LH, Koo EH (1997) The beta-amyloid precursor protein of Alzheimer's disease enhances neuron viability and modulates neuronal polarity. J Neurosci 17, 9407-9414.

[62] Ring S, Weyer SW, Kilian SB, Waldron E, Pietrzik CU, Filippov MA, Herms J, Buchholz C, Eckman CB, Korte M, Wolfer DP, Muller UC (2007) The secreted beta-amyloid precursor protein ectodomain APPs alpha is sufficient to rescue the anatomical, behavioral, and electrophysiological abnormalities of APP-deficient mice. J Neurosci 27, 7817-7826.

[63] Allinson TM, Parkin ET, Turner AJ, Hooper NM (2003) ADAMs family members as amyloid precursor protein alphasecretases. J Neurosci Res 74, 342-352.

[64] Lammich S, Kojro E, Postina R, Gilbert S, Pfeiffer R, Jasionowski M, Haass C, Fahrenholz F (1999) Constitutive and regulated alpha-secretase cleavage of Alzheimer's amyloid precursor protein by a disintegrin metalloprotease. Proc Natl Acad Sci U S A 96, 3922-3927.

[65] Postina R, Schroeder A, Dewachter I, Bohl J, Schmitt U, Kojro E, Prinzen C, Endres K, Hiemke C, Blessing M, Flamez P, Dequenne A, Godaux E, van Leuven F, Fahrenholz F (2004) A disintegrin-metalloproteinase prevents amyloid plaque formation and hippocampal defects in an Alzheimer disease mouse model. J Clin Invest 113, 1456-1464.

[66] Schroeder A, Fahrenholz F, Schmitt U (2009) Effect of a dominant-negative form of ADAM10 in a mouse model of Alzheimer's disease. J Alzheimers Dis 16, 309-314.

[67] Borchardt T, Camakaris J, Cappai R, Masters CL, Beyreuther K, Multhaup G (1999) Copper inhibits beta-amyloid production and stimulates the non-amyloidogenic pathway of amyloid-precursor-protein secretion. Biochem J 344 Pt 2, 461-467.

[68] Hiraoka Y, Ohno M, Yoshida K, Okawa K, Tomimoto H, Kita T, Nishi E (2007) Enhancement of alpha-secretase cleavage of amyloid precursor protein by a metalloendopeptidase nardilysin. J Neurochem 102, 1595-1605.

[69] Colciaghi F, Borroni B, Pastorino L, Marcello E, Zimmermann M, Cattabeni F, Padovani A, Di Luca M (2002) [alpha]Secretase ADAM10 as well as [alpha]APPs is reduced in platelets and CSF of Alzheimer disease patients. Mol Med $\mathbf{8}$, 67-74.

[70] Colciaghi F, Marcello E, Borroni B, Zimmermann M, Caltagirone C, Cattabeni F, Padovani A, Di Luca M (2004) Platelet APP, ADAM 10 and BACE alterations in the early stages of Alzheimer disease. Neurology 62, 498-501.

[71] Lannfelt L, Basun H, Wahlund LO, Rowe BA, Wagner SL (1995) Decreased alpha-secretase-cleaved amyloid precursor protein as a diagnostic marker for Alzheimer's disease. Nat Med 1, 829-832.

[72] Kim ML, Zhang B, Mills IP, Milla ME, Brunden KR, Lee VM (2008) Effects of TNFalpha-converting enzyme inhibition on amyloid beta production and APP processing in vitro and in vivo. J Neurosci 28, 12052-12061.

[73] De Strooper B, Saftig P, Craessaerts K, Vanderstichele H, Guhde G, Annaert W, Von Figura K, Van Leuven F (1998) Deficiency of presenilin-1 inhibits the normal cleavage of amyloid precursor protein. Nature 391, 387-390.

[74] Steiner H, Duff K, Capell A, Romig H, Grim MG, Lincoln S, Hardy J, Yu X, Picciano M, Fechteler K, Citron M, Kopan R, Pesold B, Keck S, Baader M, Tomita T, Iwatsubo T, Baumeister R, Haass C (1999) A loss of function mutation of presenilin-2 interferes with amyloid beta-peptide production and notch signaling. J Biol Chem 274, 28669-28673.
[75] Wolfe MS, Xia W, Ostaszewski BL, Diehl TS, Kimberly WT, Selkoe DJ (1999) Two transmembrane aspartates in presenilin-1 required for presenilin endoproteolysis and gamma-secretase activity. Nature 398, 513-517.

[76] Cruts M, Hendriks L, Van Broeckhoven C (1996) The presenilin genes: a new gene family involved in Alzheimer disease pathology. Hum Mol Genet 5 Spec No, 1449-1455.

[77] Levy-Lahad E, Wasco W, Poorkaj P, Romano DM, Oshima J, Pettingell WH, Yu CE, Jondro PD, Schmidt SD, Wang K, et al. (1995) Candidate gene for the chromosome 1 familial Alzheimer's disease locus. Science 269, 973-977.

[78] Sherrington R, Rogaev EI, Liang Y, Rogaeva EA, Levesque G, Ikeda M, Chi H, Lin C, Li G, Holman K, et al. (1995) Cloning of a gene bearing missense mutations in early-onset familial Alzheimer's disease. Nature 375, 754-760.

[79] Capell A, Steiner H, Romig H, Keck S, Baader M, Grim MG, Baumeister R, Haass C (2000) Presenilin-1 differentially facilitates endoproteolysis of the beta-amyloid precursor protein and Notch. Nat Cell Biol 2, 205-211.

[80] Jung KM, Tan S, Landman N, Petrova K, Murray S, Lewis R, Kim PK, Kim DS, Ryu SH, Chao MV, Kim TW (2003) Regulated intramembrane proteolysis of the p75 neurotrophin receptor modulates its association with the TrkA receptor. $J$ Biol Chem 278, 42161-42169.

[81] Kanning KC, Hudson M, Amieux PS, Wiley JC, Bothwell M, Schecterson LC (2003) Proteolytic processing of the p75 neurotrophin receptor and two homologs generates C-terminal fragments with signaling capability. J Neurosci 23, 54255436

[82] Marambaud P, Shioi J, Serban G, Georgakopoulos A, Sarner S, Nagy V, Baki L, Wen P, Efthimiopoulos S, Shao Z, Wisniewski T, Robakis NK (2002) A presenilin-1/gammasecretase cleavage releases the E-cadherin intracellular domain and regulates disassembly of adherens junctions. EMBO J 21, 1948-1956.

[83] Ni CY, Murphy MP, Golde TE, Carpenter G (2001) gammaSecretase cleavage and nuclear localization of ErbB-4 receptor tyrosine kinase. Science 294, 2179-2181.

[84] Sato T, Diehl TS, Narayanan S, Funamoto S, Ihara Y, De Strooper B, Steiner H, Haass C, Wolfe MS (2007) Active gamma-secretase complexes contain only one of each component. J Biol Chem 282, 33985-33993.

[85] Shirotani K, Edbauer D, Prokop S, Haass C, Steiner H (2004) Identification of distinct gamma-secretase complexes with different APH-1 variants. J Biol Chem 279, 41340-41345.

[86] Prokop S, Shirotani K, Edbauer D, Haass C, Steiner H (2004) Requirement of PEN-2 for stabilization of the presenilin $\mathrm{N}$-/C-terminal fragment heterodimer within the gammasecretase complex. J Biol Chem 279, 23255-23261.

[87] Teranishi Y, Hur JY, Welander H, Franberg J, Aoki M, Winblad B, Frykman S, Tjernberg LO (2009) Affinity pulldown of gamma-secretase and associated proteins from human and rat brain. J Cell Mol Med, in press.

[88] Campion D, Dumanchin C, Hannequin D, Dubois B, Belliard S, Puel M, Thomas-Anterion C, Michon A, Martin C, Charbonnier F, Raux G, Camuzat A, Penet C, Mesnage V, Martinez M, Clerget-Darpoux F, Brice A, Frebourg T (1999) Early-onset autosomal dominant Alzheimer disease: prevalence, genetic heterogeneity, and mutation spectrum. Am J Hum Genet 65, 664-670.

[89] Kaether C, Haass C, Steiner H (2006) Assembly, trafficking and function of gamma-secretase. Neurodegener Dis 3, 275283. 
[90] Selkoe DJ (1997) Images in neuroscience. Alzheimer's disease: from genes to pathogenesis. Am J Psychiatry 154, 1198.

[91] Shen J, Kelleher RJ, 3rd (2007) The presenilin hypothesis of Alzheimer's disease: evidence for a loss-of-function pathogenic mechanism. Proc Natl Acad Sci U S A 104, 403409.

[92] Selkoe DJ (2002) Deciphering the genesis and fate of amyloid beta-protein yields novel therapies for Alzheimer disease. $J$ Clin Invest 110, 1375-1381.

[93] Sherrington R, Froelich S, Sorbi S, Campion D, Chi H, Rogaeva EA, Levesque G, Rogaev EI, Lin C, Liang Y, Ikeda M, Mar L, Brice A, Agid Y, Percy ME, Clerget-Darpoux F, Piacentini S, Marcon G, Nacmias B, Amaducci L, Frebourg T, Lannfelt L, Rommens JM, St George-Hyslop PH (1996) Alzheimer's disease associated with mutations in presenilin 2 is rare and variably penetrant. Hum Mol Genet 5, 985-988.

[94] Filley CM, Rollins YD, Anderson CA, Arciniegas DB, Howard KL, Murrell JR, Boyer PJ, Kleinschmidt-DeMasters BK, Ghetti B (2007) The genetics of very early onset Alzheimer disease. Cogn Behav Neurol 20, 149-156.

[95] Corder EH, Saunders AM, Strittmatter WJ, Schmechel DE, Gaskell PC, Small GW, Roses AD, Haines JL, Pericak-Vance MA (1993) Gene dose of apolipoprotein E type 4 allele and the risk of Alzheimer's disease in late onset families. Science 261, 921-923.

[96] Chyung JH, Raper DM, Selkoe DJ (2005) Gamma-secretase exists on the plasma membrane as an intact complex that accepts substrates and effects intramembrane cleavage. $J$ Biol Chem 280, 4383-4392.

[97] Struhl G, Greenwald I (1999) Presenilin is required for activity and nuclear access of Notch in Drosophila. Nature $\mathbf{3 9 8}$, 522-525.

[98] Wong PC, Zheng H, Chen H, Becher MW, Sirinathsinghji DJ, Trumbauer ME, Chen HY, Price DL, Van der Ploeg LH, Sisodia SS (1997) Presenilin 1 is required for Notch1 and DII1 expression in the paraxial mesoderm. Nature 387, 288292.

[99] Fraering PC, Ye W, LaVoie MJ, Ostaszewski BL, Selkoe DJ, Wolfe MS (2005) gamma-Secretase substrate selectivity can be modulated directly via interaction with a nucleotidebinding site. J Biol Chem 280, 41987-41996.

[100] Gianni D, Zambrano N, Bimonte M, Minopoli G, Mercken L, Talamo F, Scaloni A, Russo T (2003) Platelet-derived growth factor induces the beta-gamma-secretase-mediated cleavage of Alzheimer's amyloid precursor protein through a Src-Racdependent pathway. J Biol Chem 278, 9290-9297.

[101] Desire L, Bourdin J, Loiseau N, Peillon H, Picard V, De Oliveira C, Bachelot F, Leblond B, Taverne T, Beausoleil E, Lacombe S, Drouin D, Schweighoffer F (2005) RAC1 inhibition targets amyloid precursor protein processing by gamma-secretase and decreases Abeta production in vitro and in vivo. J Biol Chem 280, 37516-37525.

[102] Henley DB, May PC, Dean RA, Siemers ER (2009) Development of semagacestat (LY450139), a functional gammasecretase inhibitor, for the treatment of Alzheimer's disease. Expert Opin Pharmacother 10, 1657-1664.

[103] Martone RL, Zhou H, Atchison K, Comery T, Xu JZ, Huang X, Gong X, Jin M, Kreft A, Harrison B, Mayer SC, Aschmies S, Gonzales C, Zaleska MM, Riddell DR, Wagner E, Lu P, Sun SC, Sonnenberg-Reines J, Oganesian A, Adkins K, Leach MW, Clarke DW, Huryn D, Abou-Gharbia M, Magolda R, Bard J, Frick G, Raje S, Forlow SB, Balliet C, Burczynski ME, Reinhart PH, Wan HI, Pangalos MN, Ja- cobsen JS (2009) Begacestat (GSI-953): a novel, selective thiophene sulfonamide inhibitor of amyloid precursor protein gamma-secretase for the treatment of Alzheimer's disease. $J$ Pharmacol Exp Ther 331, 598-608.

[104] Bateman RJ, Siemers ER, Mawuenyega KG, Wen G, Browning KR, Sigurdson WC, Yarasheski KE, Friedrich SW, Demattos RB, May PC, Paul SM, Holtzman DM (2009) A gamma-secretase inhibitor decreases amyloid-beta production in the central nervous system. Ann Neurol 66, 48-54.

[105] Saura CA, Choi SY, Beglopoulos V, Malkani S, Zhang D, Shankaranarayana Rao BS, Chattarji S, Kelleher RJ, 3rd, Kandel ER, Duff K, Kirkwood A, Shen J (2004) Loss of presenilin function causes impairments of memory and synaptic plasticity followed by age-dependent neurodegeneration. Neuron 42, 23-36.

[106] Wilcock GK, Lilienfeld S, Gaens E (2000) Efficacy and safety of galantamine in patients with mild to moderate Alzheimer's disease: multicentre randomised controlled trial. Galantamine International-1 Study Group. BMJ 321, 1445-1449.

[107] Winblad B, Black SE, Homma A, Schwam EM, Moline M, Xu Y, Perdomo CA, Swartz J, Albert K (2009) Donepezil treatment in severe Alzheimer's disease: a pooled analysis of three clinical trials. Curr Med Res Opin 25, 2577-2587.

[108] Cokugras AN (2003) Butyrylcholinesterase: structure and physiological importance. Turk J Biochem 28, 54-61.

[109] Eskander MF, Nagykery NG, Leung EY, Khelghati B, Geula $\mathrm{C}$ (2005) Rivastigmine is a potent inhibitor of acetyl- and butyrylcholinesterase in Alzheimer's plaques and tangles. Brain Res 1060, 144-152.

[110] Inestrosa NC, Alvarez A, Perez CA, Moreno RD, Vicente M, Linker C, Casanueva OI, Soto C, Garrido J (1996) Acetylcholinesterase accelerates assembly of amyloid-betapeptides into Alzheimer's fibrils: possible role of the peripheral site of the enzyme. Neuron 16, 881-891.

[111] Small DH, Moir RD, Fuller SJ, Michaelson S, Bush AI, Li QX, Milward E, Hilbich C, Weidemann A, Beyreuther K, et al. (1991) A protease activity associated with acetylcholinesterase releases the membrane-bound form of the amyloid protein precursor of Alzheimer's disease. Biochemistry 30, 10795-10799.

[112] Fu H, Li W, Luo J, Lee NT, Li M, Tsim KW, Pang Y, Youdim MB, Han Y (2008) Promising anti-Alzheimer's dimer bis(7)tacrine reduces beta-amyloid generation by directly inhibiting BACE-1 activity. Biochem Biophys Res Commun 366, 631-636.

[113] in t' Veld BA, Ruitenberg A, Hofman A, Launer LJ, van Duijn CM, Stijnen T, Breteler MM, Stricker BH (2001) Nonsteroidal antiinflammatory drugs and the risk of Alzheimer's disease. $N$ Engl J Med 345, 1515-1521.

[114] Vlad SC, Miller DR, Kowall NW, Felson DT (2008) Protective effects of NSAIDs on the development of Alzheimer disease. Neurology 70, 1672-1677.

[115] Eriksen JL, Sagi SA, Smith TE, Weggen S, Das P, McLendon DC, Ozols VV, Jessing KW, Zavitz KH, Koo EH, Golde TE (2003) NSAIDs and enantiomers of flurbiprofen target gamma-secretase and lower Abeta 42 in vivo. J Clin Invest 112, 440-449.

[116] Weggen S, Eriksen JL, Das P, Sagi SA, Wang R, Pietrzik CU, Findlay KA, Smith TE, Murphy MP, Bulter T, Kang DE, Marquez-Sterling N, Golde TE, Koo EH (2001) A subset of NSAIDs lower amyloidogenic Abeta42 independently of cyclooxygenase activity. Nature 414, 212-216.

[117] Evin G, Sernee MF, Masters CL (2006) Inhibition of gammasecretase as a therapeutic intervention for Alzheimer's dis- 
ease: prospects, limitations and strategies. CNS Drugs 20, 351-372.

[118] Hull M, Berger M, Heneka M (2006) Disease-modifying therapies in Alzheimer's disease: how far have we come? Drugs 66, 2075-2093.

[119] Szekely CA, Green RC, Breitner JC, Ostbye T, Beiser AS, Corrada MM, Dodge HH, Ganguli M, Kawas CH, Kuller LH, Psaty BM, Resnick SM, Wolf PA, Zonderman AB, WelshBohmer KA, Zandi PP (2008) No advantage of A beta 42lowering NSAIDs for prevention of Alzheimer dementia in six pooled cohort studies. Neurology 70, 2291-2298.

[120] Wilcock GK, Black SE, Hendrix SB, Zavitz KH, Swabb EA, Laughlin MA (2008) Efficacy and safety of tarenflurbil in mild to moderate Alzheimer's disease: a randomised phase II trial. Lancet Neurol 7, 483-493.

[121] Pasinetti GM (2002) From epidemiology to therapeutic trials with anti-inflammatory drugs in Alzheimer's disease: the role of NSAIDs and cyclooxygenase in beta-amyloidosis and clinical dementia. J Alzheimers Dis 4, 435-445.

[122] Pasqualetti P, Bonomini C, Dal Forno G, Paulon L, Sinforiani E, Marra C, Zanetti O, Rossini PM (2009) A randomized controlled study on effects of ibuprofen on cognitive progression of Alzheimer's disease. Aging Clin Exp Res 21, 102-110.

[123] Swerdlow RH, Khan SM (2004) A "mitochondrial cascade hypothesis" for sporadic Alzheimer's disease. Med Hypotheses $63,8-20$.

[124] Sheffler IE (1999) Mitochondria. Wiley-Liss, Inc., United States of America.

[125] Mosconi L, Mistur R, Switalski R, Tsui WH, Glodzik L, Li Y, Pirraglia E, De Santi S, Reisberg B, Wisniewski T, de Leon MJ (2009) FDG-PET changes in brain glucose metabolism from normal cognition to pathologically verified Alzheimer's disease. Eur J Nucl Med Mol Imaging 36, 811-822.

[126] Cottrell DA, Blakely EL, Johnson MA, Ince PG, Turnbull DM (2001) Mitochondrial enzyme-deficient hippocampal neurons and choroidal cells in AD. Neurology 57, 260-264.

[127] Keller JN, Schmitt FA, Scheff SW, Ding Q, Chen Q, Butterfield DA, Markesbery WR (2005) Evidence of increased oxidative damage in subjects with mild cognitive impairment. Neurology 64, 1152-1156.

[128] Markesbery WR, Kryscio RJ, Lovell MA, Morrow JD (2005) Lipid peroxidation is an early event in the brain in amnestic mild cognitive impairment. Ann Neurol 58, 730-735.

[129] Larm JA, Vaillant F, Linnane AW, Lawen A (1994) Upregulation of the plasma membrane oxidoreductase as a prerequisite for the viability of human Namalwa rho 0 cells. $J$ Biol Chem 269, 30097-30100.

[130] Atamna H, Frey WH, 2nd (2007) Mechanisms of mitochondrial dysfunction and energy deficiency in Alzheimer's disease. Mitochondrion 7, 297-310.

[131] Guzy RD, Schumacker PT (2006) Oxygen sensing by mitochondria at complex III: the paradox of increased reactive oxygen species during hypoxia. Exp Physiol 91, 807-819.

[132] Burdon RH (1995) Superoxide and hydrogen peroxide in relation to mammalian cell proliferation. Free Radic Biol Med 18, 775-794.

[133] Kawai M, Saegusa Y, Dewa Y, Nishimura J, Kemmochi S, Harada T, Ishii Y, Umemura T, Shibutani M, Mitsumori K (2010) Elevation of cell proliferation via generation of reactive oxygen species by piperonyl butoxide contributes to its liver tumor-promoting effects in mice. Arch Toxicol 84, 155-164.
[134] Bohr V, Anson RM, Mazur S, Dianov G (1998) Oxidative DNA damage processing and changes with aging. Toxicol Lett 102-103, 47-52.

[135] de Souza-Pinto NC, Bohr VA (2002) The mitochondrial theory of aging: involvement of mitochondrial DNA damage and repair. Int Rev Neurobiol 53, 519-534.

[136] Anderson S, Bankier AT, Barrell BG, de Bruijn MH, Coulson AR, Drouin J, Eperon IC, Nierlich DP, Roe BA, Sanger F, Schreier PH, Smith AJ, Staden R, Young IG (1981) Sequence and organization of the human mitochondrial genome. Nature 290, 457-465.

[137] Cantatore P, Roberti M, Rainaldi G, Gadaleta MN, Saccone C (1989) The complete nucleotide sequence, gene organization, and genetic code of the mitochondrial genome of Paracentrotus lividus. J Biol Chem 264, 10965-10975.

[138] Onyango I, Khan S, Miller B, Swerdlow R, Trimmer P, Bennett P, Jr. (2006) Mitochondrial genomic contribution to mitochondrial dysfunction in Alzheimer's disease. J Alzheimers Dis 9, 183-193.

[139] Kraytsberg Y, Kudryavtseva E, McKee AC, Geula C, Kowall NW, Khrapko K (2006) Mitochondrial DNA deletions are abundant and cause functional impairment in aged human substantia nigra neurons. Nat Genet 38, 518-520.

[140] Lin MT, Beal MF (2006) Mitochondrial dysfunction and oxidative stress in neurodegenerative diseases. Nature $\mathbf{4 4 3}$, 787-795.

[141] Bender A, Krishnan KJ, Morris CM, Taylor GA, Reeve AK, Perry RH, Jaros E, Hersheson JS, Betts J, Klopstock T, Taylor RW, Turnbull DM (2006) High levels of mitochondrial DNA deletions in substantia nigra neurons in aging and Parkinson disease. Nat Genet 38, 515-517.

[142] Parker WD, Jr., Parks J, Filley CM, Kleinschmidt-DeMasters BK (1994) Electron transport chain defects in Alzheimer's disease brain. Neurology 44, 1090-1096.

[143] Pratico D, Clark CM, Liun F, Rokach J, Lee VY, Trojanowski JQ (2002) Increase of brain oxidative stress in mild cognitive impairment: a possible predictor of Alzheimer disease. Arch Neurol 59, 972-976.

[144] Manczak M, Anekonda TS, Henson E, Park BS, Quinn J, Reddy PH (2006) Mitochondria are a direct site of A beta accumulation in Alzheimer's disease neurons: implications for free radical generation and oxidative damage in disease progression. Hum Mol Genet 15, 1437-1449.

[145] Yao J, Irwin RW, Zhao L, Nilsen J, Hamilton RT, Brinton RD (2009) Mitochondrial bioenergetic deficit precedes Alzheimer's pathology in female mouse model of Alzheimer's disease. Proc Natl Acad Sci U S A 106, 1467014675.

[146] Lustbader JW, Cirilli M, Lin C, Xu HW, Takuma K, Wang N, Caspersen C, Chen X, Pollak S, Chaney M, Trinchese F, Liu S, Gunn-Moore F, Lue LF, Walker DG, Kuppusamy P, Zewier ZL, Arancio O, Stern D, Yan SS, Wu H (2004) ABAD directly links Abeta to mitochondrial toxicity in Alzheimer's disease. Science 304, 448-452.

[147] Reddy PH, Beal MF (2008) Amyloid beta, mitochondrial dysfunction and synaptic damage: implications for cognitive decline in aging and Alzheimer's disease. Trends Mol Med 14, 45-53.

[148] Du H, Guo L, Fang F, Chen D, Sosunov AA, McKhann GM, Yan Y, Wang C, Zhang H, Molkentin JD, Gunn-Moore FJ, Vonsattel JP, Arancio O, Chen JX, Yan SD (2008) Cyclophilin $\mathrm{D}$ deficiency attenuates mitochondrial and neuronal perturbation and ameliorates learning and memory in Alzheimer's disease. Nat Med 14, 1097-1105. 
[149] Bubber P, Haroutunian V, Fisch G, Blass JP, Gibson GE (2005) Mitochondrial abnormalities in Alzheimer brain: mechanistic implications. Ann Neurol 57, 695-703.

[150] Eckert A, Hauptmann S, Scherping I, Meinhardt J, Rhein V, Drose S, Brandt U, Fandrich M, Muller WE, Gotz J (2008) Oligomeric and fibrillar species of beta-amyloid (A beta 42) both impair mitochondrial function in P301L tau transgenic mice. J Mol Med 86, 1255-1267.

[151] Gillardon F, Rist W, Kussmaul L, Vogel J, Berg M, Danzer K, Kraut N, Hengerer B (2007) Proteomic and functional alterations in brain mitochondria from $\mathrm{Tg} 2576$ mice occur before amyloid plaque deposition. Proteomics 7, 605-616.

[152] Keil U, Bonert A, Marques CA, Scherping I, Weyermann J, Strosznajder JB, Muller-Spahn F, Haass C, Czech C, Pradier L, Muller WE, Eckert A (2004) Amyloid beta-induced changes in nitric oxide production and mitochondrial activity lead to apoptosis. J Biol Chem 279, 50310-50320.

[153] Parks JK, Smith TS, Trimmer PA, Bennett JP, Jr., Parker WD, Jr. (2001) Neurotoxic Abeta peptides increase oxidative stress in vivo through NMDA-receptor and nitric-oxide-synthase mechanisms, and inhibit complex IV activity and induce a mitochondrial permeability transition in vitro. J Neurochem 76, 1050-1056.

[154] Rhein V, Baysang G, Rao S, Meier F, Bonert A, Muller-Spahn F, Eckert A (2009) Amyloid-beta leads to impaired cellular respiration, energy production and mitochondrial electron chain complex activities in human neuroblastoma cells. Cell Mol Neurobiol 29, 1063-1071.

[155] Sullivan PG, Brown MR (2005) Mitochondrial aging and dysfunction in Alzheimer's disease. Prog Neuropsychopharmacol Biol Psychiatry 29, 407-410.

[156] Casley CS, Land JM, Sharpe MA, Clark JB, Duchen MR, Canevari L (2002) Beta-amyloid fragment 25-35 causes mitochondrial dysfunction in primary cortical neurons. Neurobiol Dis 10, 258-267.

[157] Hong WK, Han EH, Kim DG, Ahn JY, Park JS, Han BG (2007) Amyloid-beta-peptide reduces the expression level of mitochondrial cytochrome oxidase subunits. Neurochem Res 32, 1483-1488.

[158] Chandrasekaran K, Hatanpaa K, Brady DR, Rapoport SI (1996) Evidence for physiological down-regulation of brain oxidative phosphorylation in Alzheimer's disease. Exp Neurol 142, 80-88.

[159] Ibanez V, Pietrini P, Alexander GE, Furey ML, Teichberg D, Rajapakse JC, Rapoport SI, Schapiro MB, Horwitz B (1998) Regional glucose metabolic abnormalities are not the result of atrophy in Alzheimer's disease. Neurology 50, 1585-1593.

[160] Minoshima S, Giordani B, Berent S, Frey KA, Foster NL, Kuhl DE (1997) Metabolic reduction in the posterior cingulate cortex in very early Alzheimer's disease. Ann Neurol 42, 85-94.

[161] Misonou H, Morishima-Kawashima M, Ihara Y (2000) Oxidative stress induces intracellular accumulation of amyloid beta-protein (Abeta) in human neuroblastoma cells. Biochemistry 39, 6951-6959.

[162] Stockley JH, Ravid R, O'Neill C (2006) Altered betasecretase enzyme kinetics and levels of both BACE1 and BACE2 in the Alzheimer's disease brain. FEBS Lett 580, 6550-6560

[163] Giliberto L, Borghi R, Piccini A, Mangerini R, Sorbi S, Cirmena G, Garuti A, Ghetti B, Tagliavini F, Mughal MR, Mattson MP, Zhu X, Wang X, Guglielmotto M, Tamagno E, Tabaton M (2009) Mutant presenilin 1 increases the expression and activity of BACE1. J Biol Chem 284, 9027-9038.
[164] Borghi R, Patriarca S, Traverso N, Piccini A, Storace D, Garuti A, Gabriella C, Patrizio O, Massimo T (2007) The increased activity of BACE1 correlates with oxidative stress in Alzheimer's disease. Neurobiol Aging 28, 1009-1014.

[165] Chen L, Na R, Gu M, Richardson A, Ran Q (2008) Lipid peroxidation up-regulates BACE1 expression in vivo: a possible early event of amyloidogenesis in Alzheimer's disease. J Neurochem 107, 197-207.

[166] Guglielmotto M, Aragno M, Autelli R, Giliberto L, Novo E, Colombatto S, Danni O, Parola M, Smith MA, Perry G, Tamagno E, Tabaton M (2009) The up-regulation of BACE1 mediated by hypoxia and ischemic injury: role of oxidative stress and HIF1alpha. J Neurochem 108, 1045-1056.

[167] Oda A, Tamaoka A, Araki W (2010) Oxidative stress upregulates presenilin 1 in lipid rafts in neuronal cells. $J \mathrm{Neu}$ rosci Res $\mathbf{8 8}, 1137-1145$.

[168] Xiong K, Cai H, Luo XG, Struble RG, Clough RW, Yan XX (2007) Mitochondrial respiratory inhibition and oxidative stress elevate beta-secretase (BACE1) proteins and activity in vivo in the rat retina. Exp Brain Res 181, 435-446.

[169] Quiroz-Baez R, Rojas E, Arias C (2009) Oxidative stress promotes JNK-dependent amyloidogenic processing of normally expressed human APP by differential modification of alpha-, beta- and gamma-secretase expression. Neurochem Int 55, 662-670.

[170] Shen C, Chen Y, Liu H, Zhang K, Zhang T, Lin A, Jing N (2008) Hydrogen peroxide promotes Abeta production through JNK-dependent activation of gamma-secretase. J Biol Chem 283, 17721-17730.

[171] Tamagno E, Guglielmotto M, Giliberto L, Vitali A, Borghi R, Autelli R, Danni O, Tabaton M (2009) JNK and ERK1/2 pathways have a dual opposite effect on the expression of BACE1. Neurobiol Aging 30, 1563-1573.

[172] Gabuzda D, Busciglio J, Chen LB, Matsudaira P, Yankner BA (1994) Inhibition of energy metabolism alters the processing of amyloid precursor protein and induces a potentially amyloidogenic derivative. J Biol Chem 269, 13623-13628.

[173] Jo DG, Arumugam TV, Woo HN, Park JS, Tang SC, Mughal M, Hyun DH, Park JH, Choi YH, Gwon AR, Camandola S, Cheng A, Cai H, Song W, Markesbery WR, Mattson MP (2010) Evidence that gamma-secretase mediates oxidative stress-induced beta-secretase expression in Alzheimer's disease. Neurobiol Aging 31, 917-925.

[174] de la Pena P, Bornstein B, del Hoyo P, Fernandez-Moreno MA, Martin MA, Campos Y, Gomez-Escalonilla C, Molina JA, Cabello A, Arenas J, Garesse R (2001) Mitochondrial dysfunction associated with a mutation in the Notch 3 gene in a CADASIL family. Neurology 57, 1235-1238.

[175] Dotti MT, De Stefano N, Bianchi S, Malandrini A, Battisti C, Cardaioli E, Federico A (2004) A novel NOTCH3 frameshift deletion and mitochondrial abnormalities in a patient with CADASIL. Arch Neurol 61, 942-945.

[176] Hansson CA, Frykman S, Farmery MR, Tjernberg LO, Nilsberth C, Pursglove SE, Ito A, Winblad B, Cowburn RF, Thyberg J, Ankarcrona M (2004) Nicastrin, presenilin, APH-1, and PEN-2 form active gamma-secretase complexes in mitochondria. J Biol Chem 279, 51654-51660.

[177] Area-Gomez E, de Groof AJ, Boldogh I, Bird TD, Gibson GE, Koehler CM, Yu WH, Duff KE, Yaffe MP, Pon LA, Schon EA (2009) Presenilins are enriched in endoplasmic reticulum membranes associated with mitochondria. Am J Pathol 175, 1810-1816.

[178] Devi L, Prabhu BM, Galati DF, Avadhani NG, Anandatheerthavarada HK (2006) Accumulation of amyloid pre- 
cursor protein in the mitochondrial import channels of human Alzheimer's disease brain is associated with mitochondrial dysfunction. J Neurosci 26, 9057-9068.

[179] Plant LD, Boyle JP, Smith IF, Peers C, Pearson HA (2003) The production of amyloid beta peptide is a critical requirement for the viability of central neurons. J Neurosci 23, 55315535 .

[180] Anandatheerthavarada HK, Devi L (2007) Mitochondrial translocation of amyloid precursor protein and its cleaved products: relevance to mitochondrial dysfunction in Alzheimer's disease. Rev Neurosci 18, 343-354.

[181] Ehehalt R, Keller P, Haass C, Thiele C, Simons K (2003) Amyloidogenic processing of the Alzheimer beta-amyloid precursor protein depends on lipid rafts. J Cell Biol $\mathbf{1 6 0}$, 113-123.

[182] Boo JH, Sohn JH, Kim JE, Song H, Mook-Jung I (2008) Rac1 changes the substrate specificity of gamma-secretase between amyloid precursor protein and Notch1. Biochem Biophys Res Commun 372, 913-917.

[183] Perluigi M, Joshi G, Sultana R, Calabrese V, De Marco C, Coccia R, Butterfield DA (2006) In vivo protection by the xanthate tricyclodecan-9-yl-xanthogenate against amyloid beta-peptide (1-42)-induced oxidative stress. Neuroscience 138, 1161-1170.

[184] Jayaprakasam B, Padmanabhan K, Nair MG (2009) Withanamides in Withania somnifera fruit protect PC-12 cells from beta-amyloid responsible for Alzheimer's disease. Phytother Res, in press.

[185] Holmes C, Boche D, Wilkinson D, Yadegarfar G, Hopkins V, Bayer A, Jones RW, Bullock R, Love S, Neal JW, Zotova E, Nicoll JA (2008) Long-term effects of Abeta42 immunisation in Alzheimer's disease: follow-up of a randomised, placebocontrolled phase I trial. Lancet 372, 216-223.

[186] Weiner HL, Lemere CA, Maron R, Spooner ET, Grenfell TJ, Mori C, Issazadeh S, Hancock WW, Selkoe DJ (2000) Nasal administration of amyloid-beta peptide decreases cerebral amyloid burden in a mouse model of Alzheimer's disease. Ann Neurol 48, 567-579.

[187] Frenkel D, Maron R, Burt DS, Weiner HL (2005) Nasal vaccination with a proteosome-based adjuvant and glatiramer acetate clears beta-amyloid in a mouse model of Alzheimer disease. J Clin Invest 115, 2423-2433.
[188] Janus C, Pearson J, McLaurin J, Mathews PM, Jiang Y, Schmidt SD, Chishti MA, Horne P, Heslin D, French J, Mount HT, Nixon RA, Mercken M, Bergeron C, Fraser PE, St George-Hyslop P, Westaway D (2000) A beta peptide immunization reduces behavioural impairment and plaques in a model of Alzheimer's disease. Nature 408, 979-982.

[189] Morgan D, Diamond DM, Gottschall PE, Ugen KE, Dickey C, Hardy J, Duff K, Jantzen P, DiCarlo G, Wilcock D, Connor K, Hatcher J, Hope C, Gordon M, Arendash GW (2000) A beta peptide vaccination prevents memory loss in an animal model of Alzheimer's disease. Nature 408, 982-985.

[190] Meilandt WJ, Cisse M, Ho K, Wu T, Esposito LA, ScearceLevie K, Cheng IH, Yu GQ, Mucke L (2009) Neprilysin overexpression inhibits plaque formation but fails to reduce pathogenic Abeta oligomers and associated cognitive deficits in human amyloid precursor protein transgenic mice. $J \mathrm{Neu}$ rosci 29, 1977-1986.

[191] Hoffmeister A, Dietz G, Zeitschel U, Mossner J, Rossner S, Stahl T (2009) BACE1 is a newly discovered protein secreted by the pancreas which cleaves enteropeptidase in vitro. JOP 10, 501-506.

[192] Azkona G, Amador-Arjona A, Obradors-Tarrago C, Varea E, Arque G, Pinacho R, Fillat C, de la Luna S, Estivill X, Dierssen M (2010) Characterization of a mouse model overexpressing beta-site APP-cleaving enzyme 2 reveals a new role for BACE2. Genes Brain Behav 9, 160-172.

[193] Zampieri N, Xu CF, Neubert TA, Chao MV (2005) Cleavage of 775 neurotrophin receptor by alpha-secretase and gammasecretase requires specific receptor domains. $\mathrm{J}$ Biol Chem 280, 14563-14571.

[194] Fortini ME (2002) Gamma-secretase-mediated proteolysis in cell-surface-receptor signalling. Nat Rev Mol Cell Biol 3, 673-684.

[195] Okochi M, Steiner H, Fukumori A, Tanii H, Tomita T, Tanaka T, Iwatsubo T, Kudo T, Takeda M, Haass C (2002) Presenilins mediate a dual intramembranous gamma-secretase cleavage of Notch-1. EMBO J 21, 5408-5416.

[196] Swerdlow RH and Khan SM (2009) The Alzheimer's disease mitochondrial cascade hypothesis: an update. Exp Neurol 218, 308-315

[197] Steiner H and Haass C (2000) Intramembrane proteolysis by presenilins. Nat Rev Mol Cell Biol 1, 217-224 